\title{
Cultural Studies of Science Education
}

\section{Impact of initiatives to implement science inquiry - a comparative study of the Turkish, Israeli, Swedish and Czech science education systems. \\ --Manuscript Draft--}

Manuscript Number:

Full Title:

Article Type:

Keywords:

Corresponding Author:
CSSE-D-14-00038R6

Impact of initiatives to implement science inquiry - a comparative study of the Turkish, Israeli, Swedish and Czech science education systems.

Article

Science inquiry; IBSE; Implementation; science education

Jana Heinz, Dr.

Technische Universität München

Munich, GERMANY

Corresponding Author Secondary

Information:

Corresponding Author's Institution:

Technische Universität München

Corresponding Author's Secondary Institution:

First Author:

Jana Heinz, Dr.

First Author Secondary Information:

Order of Authors:

Jana Heinz, Dr.

Margareta Enghag

Iva Stuchlikova

Gultekin Cakmakci

Ran Peleg

Ayelet Baram-Tsabari

Order of Authors Secondary Information:

Funding Information:

Abstract:

Response to Reviewers:

This empirical study investigates factors that influence the implementation of science inquiry in the education systems of Turkey, Israel, Sweden and the Czech Republic. Data was collected by means of recordings of science experts' discussions as part of an EU-funded project called Science-Teacher Education Advanced Methods (20092012). Results of the qualitative analysis reveal that the following general indicators provide insight into the extent of implementation of inquiry-based science education (IBSE): (1) curriculum (2) assessment (3) policy and (4) teacher professionalization systems. In a second step comparative analyses of the four countries' education systems were conducted with regard to these indicators. To compare these factors we refer to both the framework of neo-institutional theories that explore the emergence of isomorphic educational models and to results from comparative studies emphasizing the influence of the countries' individual structure and cultural practices on modifying global pressure to convergence. Results show that in each of the countries these indicators influence the implementation of science inquiry to varying degrees. Moreover, as a result of the comparative analyses further country specific factors important for implementing science inquiry were found: (5) the need to improve existing teaching methods, (6) predominant teaching patterns, (7) infrastructure that enables changes in education and (8) education system's general goals that correlate with reforms.

Dear Kate and Cath,

Thank you very much for your suggestions to improve the article.

Accordingly to your suggestions we revised all parts, where changes were identified 
and provided the executive summary in English as well as the executive summaries in Turkish, Hebrew, Swedish and Czech.

We hope, the article now meets your standards.

Kind regards,

Jana 


\section{Impact of initiatives to implement science inquiry - a comparative study of the Turkish, Israeli, Swedish and Czech science education systems.}

Jana Heinz, Margareta Enghag, Iva Stuchlikova, Gultekin Cakmakci, Ran Peleg and Ayelet Baram-Tsabari

\section{J. Heinz ()}

TUM School of Education, Technische Universität München, Arcisstraße 21, 80333 München, Germany e-mail: jana.heinz@tum.de

M. Enghag, Department of Mathematics and Science Education, Svante Arrhenius väg 20A, 10691 Stockholm, Sweden

I. Stuchlikova, Department of Pedagogy and Psychology, Faculty of Education, University of South Bohemia, Ceske Budejovice, Czech Republic

G. Cakmakci, Faculty of Education, Department of Science Education, Hacettepe University, 06800, Ankara, Turkey

R. Peleg, Faculty of Education, University of Haifa, Israel

A. Baram-Tsabari, Department of Education in Science and Technology, Technion - Israel Institute of Technology, Israel 


\title{
Impact of initiatives to implement science inquiry - a comparative study of the Turkish, Israeli, Swedish and Czech science education systems.
}

\begin{abstract}
This empirical study investigates factors that influence the implementation of science inquiry in the education systems of Turkey, Israel, Sweden and the Czech Republic. Data was collected by means of recordings of science experts' discussions as part of an EU-funded project called Science-Teacher Education Advanced Methods (2009-2012). Results of the qualitative analysis reveal that the following general indicators provide insight into the extent of implementation of inquiry-based science education (IBSE): (1) curriculum (2) assessment (3) policy and (4) teacher professionalization systems. In a second step comparative analyses of the four countries' education systems were conducted with regard to these indicators. To compare these factors we refer to both the framework of neo-institutional theories that explore the emergence of isomorphic educational models and to results from comparative studies emphasizing the influence of the countries' individual structure and cultural practices on modifying global pressure to convergence. Results show that in each of the countries these indicators influence the implementation of science inquiry to varying degrees. Moreover, as a result of the comparative analyses further country specific factors important for implementing science inquiry were found: (5) the need to improve existing teaching methods, (6) predominant teaching patterns, (7) infrastructure that enables changes in education and (8) education system's general goals that correlate with reforms.
\end{abstract}

Keywords Science inquiry $\cdot$ IBSE $\cdot$ Implementation $\cdot$ Science education

\section{Özet}

Bu deneysel çalışma, Türkiye, İsrail, İsveç ve Çek Cumhuriyetleri eğitim sistemlerindeki bilimsel sorgulama uygulamalarını etkileyen faktörleri araştırmaktadır. Avrupa Birliği tarafından desteklenen Fen Öğretmen Eğitimi İleri Metotlar (2009-2012) isimli proje kapsamında bilim uzmanları tarafından yapılan tartışmalarının ses kayıtları bu çalışmanın verilerini oluşturmaktadır. 
Nitel analiz sonuçları aşağıdaki genel göstergelerin sorgulamaya dayalı fen eğitiminin (IBSE) hangi ölçüde uygulandığının yapısını ortaya çıkarılmasını sağlamıştır: (1) öğretim programı, (2) değerlendirme, (3) politika ve (4) öğretmen profesyonelleşme sistemleri. Bu göstergeler 1şığında bu dört ülkenin eğitim sistemleri ikinci kez karşılaştırmalı analize tabi tutulmuştur. Bu faktörleri karşılaştırmak için hem eşbiçimlik eğitim modellerinin oluşumunu araştıran yeni kurumsalcılık teorilerin çerçevesine ve hem de ülkelerin bireysel yapılarının etkisine vurgu yapan ve küresel baskı ile kültürel pratiklerin yakınlaşmasına yönelik karşılaştırmalı çalışmalara başvurduk. Sonuçlar her bir ülke için bu göstergelerin bilimsel sorgulama uygulamalarını farklı derecelerde etkilediğini göstermiştir. Ayrıca karşılatırmalı analizler sonucunda bilimsel sorgulama uygulamaları için önemli olan başka faktörler de bulunmuştur: (5) mevcut öğretim yöntemlerini geliştirme ihtiyacı, (6) baskın öğretim desenleri, (7) eğitimde değişime olanak sağlayan altyapı ve (8) reformlar ile bağdaş olan eğitimin genel amaçları.

השפעה של יוזמות ליישום חקר מדעי בכיתה - מחקר השוואתי של מערכות חינוך מדעי בטורקיה, ישראל, שוודיה וצ'כיה הוראת מדעים מבוססת חקר (IBSE - Inquiry Based Science Education) זכתה לתשומת לב מחקרית ומעשית רבה. כחלק ממגמה זו תמך האיחוד האירופאי במגוון רב של פרוייקטים שמטרתם לקדם הוראת מדעים מבוססת חקר. עם זאת, למרות ההסכמה הרחבה לגבי חשיבותה של הוראת המדעים מבוססת חקר, הדרך והתדירות בה היא מייושמת במערכות שונות מגוונת. מטרת מחקר זה היא לבדוק אלו תנאים קשורים בהצלחתן של יוזמות שמטרתן לקדם הוראת המדעים מבוססת חקר.

מחקר אמפירי זה חוקר גורמים המשפיעים על היישום של חקר בהוראת המדעים במערכות החינוך של טורקיה, ישראל, שוודיה וצ'כיה. הנתונים נאספו באמצעות הקלטות דיונים של מומחים בהוראת S-TEAM: Science Teacher המדעים, שהתנהלו כחלק מפרויקט במימון האיחוד האירופי שנקרא Education Advanced Methods הוראת מדעים מבוססת חקר על ידי פיתוח מקצועי והכשרת מורים בשיטות פדגוגיות חדשניות. ממצאי הניתוח האיכותני מורים כי ניתן להבין את היקף היישום של חינוך מדעי מבוסס חקר בעזרת האינדיקטורים הבאים: (1) תוכנית הלימודים, (2) הערכה, (3) מדיניות ו-(4) מערכות להכשרת מורים. בשלב השני נעשו ניתוחים השוואתיים של מערכות החינוך של ארבע המדינות ביחס לאינדיקטורים אלו. כדי להשוות גורמים אלה אנו מתייחסים למסגרת של תיאוריות הניאו-מוסדיות (neo-institutional theories) ממחקרים השוואתיים קודמים, המדגישים את השפעת המבנה ומנהגים התרבותיים של המדינה על 
שינויים בלחץ הגלובלי להתכנסות. הממצאים מצביעים על כך שבכל אחת מהמדינות שהשתתפו במחקר אינדיקטורים אלו השפיעו במיזה מסויימת על ישומו של חקר מדעי בכיתה. מעבר לכך, כתוצאה מהניתוחים ההשוואתיים עלו גורמים הספציפיים לכל מדינה שהיו חשובים בישום החקר המדעי כשיטת הוראה: (5) הצורך בשיפור שיטות הוראה קיימות, (6) תבניות הוראה מובילות, (7) תשתית המאפשרת שינויים בחינוך ו-(8) מטרות מערכת החינוך הנמצאות בהלימה עם רפורמות.

\section{Sammanfattning}

Denna empiriska studie undersöker faktorer som påverkar implementering av undervisning med ett undersökande arbetssätt (inquiry based science education, IBSE) inom utbildningssystemen i Turkiet, Israel, Sverige och Tjeckien. Data samlades in med hjälp av inspelningar av experter pånaturvetenskaplig utbildning i diskussioner som en del av en EU-finansierat projekt S-TEAM (Science-Teacher Education Advanced Methods (2009-2012). Resultat från den kvalitativa analysen visar först att följande allmänna indikatorer ger en inblick i omfattningen avgenomförandet av naturvetenskaplig undervisning med ett undersökande arbetssätt(IBSE): (1) läroplan (2) bedömning (3) politik och (4) system för lärares fortbildning. I ett andra steg genomfördes jämförande analyser av de fyra ländernas utbildningssystem med avseende på dessa indikatorer. För att jämföra faktorer, refererar vi dels till ett neo-politiskt ramverk, vilket undersöker förekomsten av isomorfa utbildningsmodeller, och dels till resultat från jämförande studier som uppmärksammar ländernas individuella strukturer och kulturella praktiker för att modifiera det globala trycket mot konvergens. Resultaten visar att indikatorerna påverkar implementering av undervisning med ett undersökande arbetssätt (IBSE) i varierande grad i var och en av länderna. Dessutom, som en följd av de jämförande analyserna, konstaterades ytterligare land-specifika faktorer som är viktiga för genomförandet av undervisning med ett undersökande arbetssätt: (5) behov av att förbättra befintliga undervisningsmetoder, (6) dominerande undervisningsmönster,(7) infrastruktur som möjliggör förändringar i utbildningen och (8) att utbildningssystemets allmänna mål korrelerar med reformer. En reflektion från de svenska nationella samtalsdagarna som datainsamlingen är hämtat ifrån, är att de skolpolitiska förutsättningarna är planerade så långt fram i tiden att de reformer som initieras från ett EU-projekt som S-TEAM har svårt att få genomslag på politisk nivå. Svenska läro-och kursplaner reglerar inte hur undervisning bedrivs men ställer krav på ett centralt innehåll, och har övergripande målsättningar med avseende på värdegrund och skolans uppdrag. Detta ställer stora krav på svenska lärarutbildningsprogram vid 
universiteten att införa inquiry baserad undervisning för att kunna realisera lärarutbildning- och fortbildning, som ger lärarkompetens att undervisa efter de svenska styrdokumentens intentioner vilka kan realiseras med mer av ett undersökande arbetssätt. Här krävs ett utökat samarbete mellan naturvetenskapsdidaktiker och ämnesinstitutionerna.

\section{Shrnutí}

Požadavky na zlepšení přírodovědného a matematického vzdělávání v Evropě vedly ke snahám o nadnárodní aktivity, které by ovlivnily národní vzdělávací praxi. V rámci evropských rámcových projektů byly realizovány diseminační aktivity, které směřovaly $\mathrm{k}$ rozšiřrování dobré praxe $\mathrm{v}$ nadnárodním měřítku. Evropské projekty, které $\mathrm{k}$ tomu směřovaly, ukázaly, že širší uplatnění pedagogického konceptu badatelsky orientovaného prrírodovědného a matematického vzdělávání (IBSE) nezbytně vyžaduje přijmout podpůrná opatření. Hledání toho, jak mají být tato opatření zaměřena, je předmětem i předkládaného textu. Tato empirická studie zkoumá faktory, které ovlivňují realizaci badatelsky orientovaného vyučování ve výuce př́rodovědných předmětů a matematiky $\mathrm{v}$ Turecku, Izraeli, Švédsku a v České republice. Data, z nichž studie vychází, byla shromážděna v rámci projektu 7. Rámcového programu EU nazvaného ScienceTeacher Education Advanced Methods, řešeného v letech 2009-2012. Pro tuto studii byla použita analýza audiozáznamů diskusí národních expertních panelů, která byla zpracována otevřeným a posléze axiálním nehierarchickým kódováním. Výsledky kvalitativní analýzy ukázaly, že míra uskutečňování badatelsky orientovaného prŕrodovědného a matematického vyučování (IBSE) v zúčastněných zemích souvisí s následujícími hlavními faktory: (1) kurikulum, (2) hodnocení, (3) vzdělávací politika, (4) systém profesního rozvoje učitelů. Vyšší pravděpodobnost rozsáhlejšího uplatňování IBSE je tam, kde je kurikulum jasně a explicitně zacíleno na badatelsky orientovaný přístup k vyučování a učení. Uplatňování IBSE je dále významně ovlivněno způsoby hodnocení práce žáků, které učitelé používají, což se odvíjí od struktury kurikula a převažujících způsobů výuky v dané zemi. Nezbytné je dále, aby IBSE bylo významně podpořeno vzdělávací politikou - nejen v rovině samotného prrírodovědného kurikula, ale $\mathrm{i}$ př́ípravy a profesního rozvoje učitelů. IBSE je závislé i na tom, nakolik je 
efektivně začleněno do dalšího vzdělávání učitelů. V další části studie byly tyto faktory sledovány ve srovnávací analýze vzdělávacích systémů čtyř zúčastněných zemí. Tato analýza přihlíží jednak k tlakům, které vedou k postupnému sbližování národních vzdělávacích systémů, tak jak jsou popsány $\mathrm{v}$ neoinstitucionálních teoriích; jednak k výsledkům srovnávacích studií, které ukazují, že proměny vzdělávacích systémů ve směru uvedené konvergence jsou ovlivněny národně specifickými podobami struktury vzdělávacího systému a kulturně vázaných vzdělávacích tradic. Výsledky ukazují, že v každé ze zúčastněných zemí studované faktory ovlivňují realizaci badatelsky orientovaného př́rodovědeckého a matematického vyučování různou měrou. Ze srovnávací analýzy navíc vyplynuly další faktory, které se ukazují jako podstatné pro implementaci badatelského vyučování, jako jsou (5) potřeba zlepšit existující výukové postupy a metody, (6) převažující způsoby výuky v dané zemi, (7) infrastruktura, která umožňuje změny ve vzdělávání, (8) hlavní cíle vzdělávacího systému. Uplatňování IBSE je v dané zemi podpořeno, pokud si klíčoví aktéri přírodovědného vzdělávání uvědomí nutnost změny stávajících výukových metod a podpoří ji. Takové uvědomění je často spojeno s horšími nebo zhoršujícími se národními výsledky v mezinárodních šetřeních výsledků učení žáků. Ochotu začít ve větším rozsahu používat badatelských forem výuky značně ovlivňuje to, nakolik převažující styly výuky v dané zemi obsahují dílčí prvky badatelského př́stupu. Významným faktorem je také vybavenost škol pro tento způsob výuky. Důležité je však zejména to, nakolik IBSE odpovídá hlavním cílům národní vzdělávací strategie, pokud tomu tak je, větší zastoupení badatelských forem výuky získává vyšší prioritu.

Inquiry-based science education (IBSE) has received much attention in science education following influential projects like "La main à la pate" (Eurydice 2011, p. 38f) or the National science education standards of the US in 1996 (National Research Council 1996). The focus on science inquiry is also reflected in a variety of initiatives in EU education policy (ALLEA Working Group 2012). This study explores conditions that influence the impact of initiatives aimed at improving science education by 
disseminating science inquiry. Data was collected from recorded science education experts' discussions in four countries within the European project Science-Teacher Education Advanced Methods (S-TEAM) (http://s-teamproject.eu), the objective of which was to support teachers in Europe in using inquiry-based science methods and thereby improving pupils' attitudes and competencies. The comparative approach of this study requires both an analysis of general factors that influence reform efforts in education, and the elaboration of country-specific frameworks.

\section{Background}

The project S-TEAM aimed at improving European students' science competencies and attitudes towards science by disseminating science inquiry. Three objectives were addressed in particular:

- improving motivation, learning and pupil attitudes in European science education (objective 1: student engagement);

- enabling large numbers of teachers to adopt advanced methods for more effective science teaching (objective 2: teacher empowerment); and

- $\quad$ supporting teachers by providing professional development for advanced methods (objective 3: teacher education).

To implement these objectives, S-TEAM combined the state-of-the art knowledge about science education with practical experience in teacher education. In order to implement innovative science teaching methods in Europe on a large scale, 25 organizations in 15 countries were involved. The dissemination approach of S-TEAM particularly included three aspects: (1) creating networks across European countries, (2) reaching many 
cooperation partners and stakeholders in Europe, and (3) spreading student-centred science education methods, in particular science inquiry across countries (S-TEAM 2009).

The project was part of the European Commission (EC) approach to provide resources to better connect Europe's education systems to changing demands of society, especially of the labour market in an increasingly competitive globalized world (EC 2007b). Due to the European Union's limited competence in educational governance and the lack of mandatory guidelines to implement science inquiry in the participating countries, the ways to put these new teaching approaches into practice have presented different challenges in each country.

To investigate the effects of such a "soft governance" reform in science education, we refer to the framework of neo-institutional theories that explore the emergence of isomorph educational models. Moreover, we take a stance on the theoretical approaches analysing how global pressures to convergence are modified by the countries' individual educational structures and traditions.

Research on current developments in education identify a global pressure on nations' education systems to become more similar and to emulate best or good practices, codified in European policies (Powell and Solga 2010, p. 708). Gili Drori and John Meyer (2006) point out that the rise in the number of intercultural policies can be linked to the rise of science as a dominant cultural model worldwide. This cultural model, in their view, is based on Western paradigms of rationality, and is becoming evident in the increasing authority of science and an expansion of its scope. The influence of these rationalized environments on education systems and on emerging global education models are explained by studies based on neo-institutional theories. These approaches focus on organizations' specific institutionalized practices that influence their actions 
and on their institutional environments that provide social norms and expectations about how they should function (Meyer 2008). According to Walter Powell and Paul DiMaggio (1991) organizational change takes place primarily, as organizations try to reach legitimacy by using rules and norms that are widely valued in their organizational environment. As Michael Dobbins and Christoph Knill (2009) show, especially in phases of insecurity, organizational adjustment to the environment takes place by imitating structures of similar organizations that are perceived to be successful. Moreover, organizational change can also take place due to coercion resulting from financial or legal dependencies (Powell and DiMaggio 1991, p. 74).

Other studies that analyse changes in the area of education from an international perspective focus on models of shared frameworks or transnational communication. Berit Karseth and Tone Dyrdal Solbrekke (2010), for instance, explain how such shared frameworks can emerge as a result of transnational communication and how they affect similar developments in educational models. Shared frameworks, together with mechanisms, such as indicators, benchmarking and best practices, can be typically found in intergovernmental cooperation between European Union states, as Isabelle Bruno (2009) found in analysing tools of neoliberal governing. In another study Torben Heinze and Christoph Knill identify transnational communication as a driving force for policy convergence. Similarly to the mechanisms identified by Powell and Solga (2010) or Bruno (2009), the authors point out to processes like lesson-drawing, emulation, transnational problem-solving, and the promotion of policies by international organizations that lead to isomorphic effects in educational policy (Heinze and Knill 2008, p. 497).

Research on convergence or divergence of education systems resulting from global trends emphasize the impact of country-specific factors, yet to different degrees: From 
the perspective of neo-institutional theories, national footprints that can be seen in the countries' education systems are nevertheless thought to be part of the same transformation process that is mainly influenced by scientised logics (Powell and Solga 2010, p. 712-713). In contrast to neo-institutionalist or world culture approaches, numerous studies that employ an empirical comparative approach to educational trends emphasize that national disparities result from different cultural and structural characteristics of the education systems, so that global reforms are adapted to national or local contexts. As Jan Germen Janmaat, Marie Duru Bellat, Andy Green and Philippe Mehaut (2013) show, attempts to harmonize or standardize multiple countries' education systems are hindered by effects of (1) the specific societies' socio-economic development that is connected with its education system, (2) differences in the societies' social and institutional characteristics as well as (3) specific cultural traditions. Other studies argue that institutions which offer stability and prevent changes are responsible for variance in the acceptance or resistance to international reforms. As described in the theory of loose coupling, organizations have a variety of strategies at their disposal to respond to environmental changes, which therefore often takes place at a superficial level (Orton and Weick 1990).

Against these theoretical strands, it is the objective of this article to develop a theoretical framework to analyse the effects of the S-TEAM objective to disseminate science inquiry which can be regarded as a cross-national educational reform approach. We combine research on the influence of supranational influences and national explanatory variables to analyse the status of implementation of science inquiry. In particular, as the project's approach to disseminate science inquiry is based on soft forms of governance we expect to find variations in the individual countries' responses to the objective to improve science education. We argue that the implementation of 
science inquiry is likely to be influenced by the characteristics of the countries' educational systems as well as by cultural traditions of science education exposing the key role of teachers' priorities and local political agendas.

\section{Science Inquiry}

The increasing importance of science inquiry has been accompanied by criticism about the ambiguity of the term and its specific components (Furtak et al. 2012). Generally speaking, science inquiry can refer to three different ideas in education: (1) a set of skills to be learned by students; (2) a cognitive understanding of the processes of inquiry, for example the logic of a controlled experiment; and (3) a pedagogical strategy (Gyllenpalm, Wickman and Holmgren 2010). With regard to skills students should acquire, Rodger Bybee for instance, points out, "Inquiry shifts the focus of education to cognitive abilities such as reasoning with data, constructing an argument, and making a logically coherent explanation. On the most basic level, inquiry refers to the process of doing science. Inquiry-based learning engages students in the investigative nature of science. Using inquiry to teach science helps students put materials into context; fosters critical thinking; engages students more fully, resulting in positive attitudes toward science; and improves communication skills" (Bybee 2010, p. 131).

Concerning science inquiry as a pedagogical strategy, the levels of inquiry employed in science education can be differentiated by the relative number of teacher-directed versus student-directed behaviours during the activity. Thorsten Bell and colleagues (2005), for instance, describe four inquiry categories varying in the amount of information provided by the teacher, ranging from strongly teacher-directed inquiry, in which the student is provided the most information, to "open inquiry", where students formulate the research question, methods and solution on their own. In the projectSTEAM, the partners agreed up on the following definition, of Marcia Linn, Elizabeth 
Davis and Philip Bell, which we will employ in this study: "[Inquiry is] the intentional process of diagnosing problems, critiquing experiments, and distinguishing alternatives, planning investigations, researching conjectures, searching for information, constructing models, debating with peers and forming coherent arguments" (2004, p. 4).

While science inquiry is a significant main focus in the US and European science research and education policy, there is a lack of knowledge on the conditions that influence its implementation. In Europe, this can be attributed to the considerable variation that exists between the educational systems in each country. Accordingly, inquiry-based science is implemented to differing degrees in each country's science education system. However, as reforms in education have to be adjusted to local situations and problems, it is necessary to know about the degree, to which IBSE is already implemented in the educational system of a country, especially in the countries' science curricula, its teacher education and teacher professional development (TPD) programs as well as about its current practice in science instruction (Inter Academics Panel 2006).

\section{Science inquiry in European science education}

Empirical investigations emphasize the diversity regarding the degree to which IBSE is part of a country's science education, especially with regard to the framework conditions and their stages of preparedness for the transition to a new, inquiry-based educational system (IEA 2012a). Still, research concludes that fundamental elements of IBSE are part of the science instruction, curricula and teacher professionalization systems. Furthermore, these studies report that science inquiry features, like dialogues, discussion and collaborative working, are frequently recommended in European educational policy documents. 
Similar results are provided by studies that investigate how IBSE is implemented in the European teacher professionalization systems. Doris Jorde and others (2012) administered two surveys with partners of S-TEAM in the fifteen participating countries in 2009 and 2011. Their questionnaires focused on the national structure of teacher education, teacher professional development and science curricula. Furthermore, participants were asked if and how IBSE is integrated in teacher education and in TPD. Results showed that in all of the participating countries IBSE is part of teacher education and TPD modules but to varying degrees and in different forms. The authors found that in most cases IBSE is part of didactic courses and in fewer cases it is taught in science and pedagogical courses $(2012$, p. 26). Even if countries have national curricula these do not provide specific details on the content of the courses. Rather, the individual institutions can autonomously choose the content for courses in teacher education and TPD. Courses on IBSE take place in differing forms, too. TPD modules on IBSE are offered by national organisations as well as private institutes and range from one-day seminars to courses that take place on a longer period.

Regarding the organization of science classes in different countries, large scale assessment studies of student achievements, such as PISA and TIMSS, provide information. In addition to their focus on the scientific literacy of students, they also provide insight into teaching patterns of different countries (OECD 2011). A key finding of these comparative studies is that culturally embedded concepts of instruction shape and reproduce communication and action structures in the classroom (Hiebert and Stigler 2000). The TIMSS 1999 Science Video Study, for instance, examined teaching practices in the Czech Republic, Japan, Australia, the Netherlands and the United States (Roth and Garnier 2006). The videos revealed many common features in these countries with regard to instructional organization, science content and student actions. 
Nevertheless, each country had a distinct approach to science teaching (Roth et al. 2006) based on widely shared mental models of teaching, or cultural "scripts" (Hiebert and Stigler 2000). With regard to science inquiry practices, students in Japanese and Australian science lessons had more opportunities to collect and record first hand data or phenomena related to independent practical activities than students in Czech, Dutch and U.S. science lessons (Roth et al. 2006). Other studies base their analyses on student questionnaires to obtain insight into the setup of science instruction (IEA 2012). In PISA 2006 teaching and learning of science was investigated by means of an analysis of typical classroom activities. Students were asked how often specific learning activities occur in their science classes during the course of the school year. Results of latent class analysis show distinct patterns of student activities, experiments and forms of science inquiry (Seidel et al. 2007). Three different teaching patterns were identified: typical for teaching pattern I is that in nearly all lessons students plan their own investigations, conduct experiments, draw conclusions, explain own ideas and relate scientific concepts to the world outside school. Teaching pattern II is characterized by fewer opportunities for students to plan and conduct their own experiments, but they more often draw conclusions and render concrete practical experiences. Science teaching pattern III contains few elements of science inquiry. In the European countries the three different teaching patterns are used to differing degrees. In most countries, like Germany, Finland, France, Norway and Sweden teaching pattern II predominates, teaching pattern I is practiced mainly in Turkey while students in the Czech Republic report that they are taught by teaching pattern III most often (Seidel et al. 2007, p. 166).

In summary, these studies show that science inquiry has been implemented in the European countries curricula largely. Its application in the teacher professionalization systems, however, varies substantially as these systems operate in a decentralized 
manner. With regard to the degree to which IBSE is practiced in classrooms, the great importance of culturally shaped teaching patterns that have been reproduced over several generations of teachers become apparent. Thus, the differing educational structures and cultural patterns of a country constitute specific framework conditions that influence the degree to which IBSE will be implemented in the educational systems.

Moreover, numerous studies have been conducted which identify factors that influence the success of reform initiatives in education. The majority of research on the implementation of reforms in education focuses on two major aspects: teacher professionalization and strategies to implement innovations in the educational infrastructure of school systems.

\section{Effective reform initiatives in education}

Teachers, whose expertise and attitudes towards innovations should be acknowledged, are regarded as key actors in implementing innovations in the classrooms (Ostermeier, Prenzel and Duit 2010). The majority of studies about teacher professionalization agrees that a high quality TPD program, that is characterized by a long-term, collaborative and situated approach (Casotti, Rieser-Danner and Knabb 2008), is key to modifying teaching methods. Furthermore, as surveys have shown that teachers are often unfamiliar with IBSE approaches, the cooperation of teacher colleagues in bringing IBSE into classroom is seen as an effective tool to address questions concerning classroom management and guiding student learning (Campbell, Zhang and Neilson 2011). Another feature that research has identified to ease the implementation of reform-orientated teaching is the close connection between teaching on the one hand and self-evaluation and assessment on the other (Duschl 2008). 
Research on factors that heavily influence the success of innovations in the classroom, moreover, emphasize the institutionalization of reform initiatives (European Commission 2007a). In summarizing the experiences with implementing teaching reforms, Michael Fullan for instance concludes, "Internal school development is a core requirement, but such change cannot occur unless the school is actively connecting to the outside" (2002, p. 583). The external infrastructure Fullan speaks of includes a variety of stakeholders in science (2010). Thus, new methods in teaching need evidence of their effectiveness from educational research to convince stakeholders in science teaching to support IBSE (Heinz, Lipowski, Gröschner and Seidel 2012). In addition to integrating IBSE into teacher professionalization programs, teachers and principals in schools are regarded as crucial in the implementation of IBSE. Furthermore, as shown above support by representatives in the area of educational policy is necessary to integrate IBSE in science curricula. Parents and community are regarded as further stakeholders that facilitate the use of IBSE in schools as they have an impact in children's learning and pass on attitudes towards science (Henderson and Mapp 2002). Other requirements for institutionalizing reforms in education are seen in incentives to introduce innovative teaching approaches on large scale. It is suspected that only intrinsically motivated teachers will participate in TPD programs (Elmore and Fuhrman 1995). Therefore, Richard Elmore suggests: “[creating] strong professional and social normative structures for good teaching practice that are external to individual teachers and their immediate working environment" (1996, p. 18).

In this context, the majority of research on the implementation of reform projects in science education focuses on single initiatives within one country but neglect a research approach that compares countries. There is a lack of knowledge of factors that influence the implementation of teaching reforms in science education from an international 
perspective. A comparative approach can identify the unique characteristics of each country as well as explore common characteristics that influence the implementation of IBSE in science teaching.

\section{Methods}

\section{Research Question}

To obtain more information on conditions that influence the implementation of IBSE, the following research questions are addressed by this study:

1. Which indicators provide insight into the state of implementation of IBSE in the participating countries' education systems?

2. Which country specific frameworks influence the implementation of IBSE?

\section{Method}

The EU-project S-TEAM organized national workshops in all participating countries in 2009 and 2010 (S-TEAM 2009). Important stakeholders of the countries' education system were invited to discuss the degree of implementation of IBSE and ways to further disseminate this approach in science education. In the seminars, an overview of European educational policy and best practices in science education with a special emphasis on inquiry-based science teaching was given by members of the S-TEAM project. Then, discussions were initiated as to whether components of this model might potentially be used to improve TPD in the respective countries. These discussions were recorded. The resulting database of this study includes the qualitative data from 66 participants from Turkey, Israel, Sweden and the Czech Republic. 


\section{Analyses}

To answer the first research question, indicators resulting from the qualitative analyses of the workshop recordings were derived. The national workshop transcripts were coded by the authors of this study, using open codes and then flat (non-hierarchical) axial coding leading to the main categories. These were inductively derived after recognizing repeatingly occurring phenomena by examining similarities and differences, employing the methodology of the Grounded Theory (Corbin and Strauss 1990). These phenomena were integrated with theoretical concepts important for implementing reforms in science education. Taken together, these indicators explain, which factors and conditions must be met to implement science inquiry in the long term in most education systems. In a second step, we compared this theoretical framework with the context in the individual countries and analysed how differently these indicators are positioned in the four countries under review. We were thus able to identify cultural specific patterns and variations. To show the country specific variations concerning these indicators and thereby the differing states of implementation of IBSE we used extensive secondary literature about science education in Europe, as for instance from the internet based research tool Web of Science, publication from large-scale assessment studies or EUpublications.

\section{Participants}

As seen in Table 1, 66 participants took part in the national workshops in Turkey, Israel, Sweden and the Czech Republic.

Table 1

Number of Participants per Country

\begin{tabular}{lrrrrr}
\hline Participants & \multicolumn{5}{c}{ Country } \\
\hline & TUR & ISR & SW & CR & total
\end{tabular}


Teachers

teacher educators/

educational researchers

school principles

discipline leader

administrators/

ministry civil servants

Politicians

stakeholders (e.g.

representatives of unions)

Others

Total
8

2

7

1

2

11

1

3

1

2

33

4

2

20

1

3

1

21
15

18
66

From this data the conclusion can be drawn that the majority of workshop participants work as teacher educators at universities and research institutions. Further large group of participants are administrators and civil servants at ministries and school leaders. Thus, the participants may be familiar with science education in the areas of teacher professionalization or in educational administration and policy and therefore should be experts for science education in their countries.

\section{Results I: Which indicators provide insight into the state of implementation of IBSE in the participating countries education systems?}

To answer the first research question, recordings of the workshops in Turkey, Israel, Sweden and the Czech Republic were coded. Analysing these recordings with regard to factors influencing the implementation of IBSE - the pedagogical concept to be implemented (see Figure 1) - the following indicators could be created: (1) curriculum 
(2) assessment (3) policy and (4) teacher professionalization systems. These will be discussed in the following sections. In a second step comparative analyses of the four countries' education systems were conducted with regard to these indicators. Results show that in each of the countries these indicators influence the implementation of science inquiry to varying degrees. Furthermore, as a result of the comparative analyses more factors important for implementing science inquiry were found: (5) the need to improve existing teaching patterns, (6) predominant teaching patterns of a country, (7) infrastructure that enables changes in education and (8) support for reforms by the education system's general goals. These factors are presented in Figure 1 and are discussed further in the following section.

Figure 1: Influencing factors

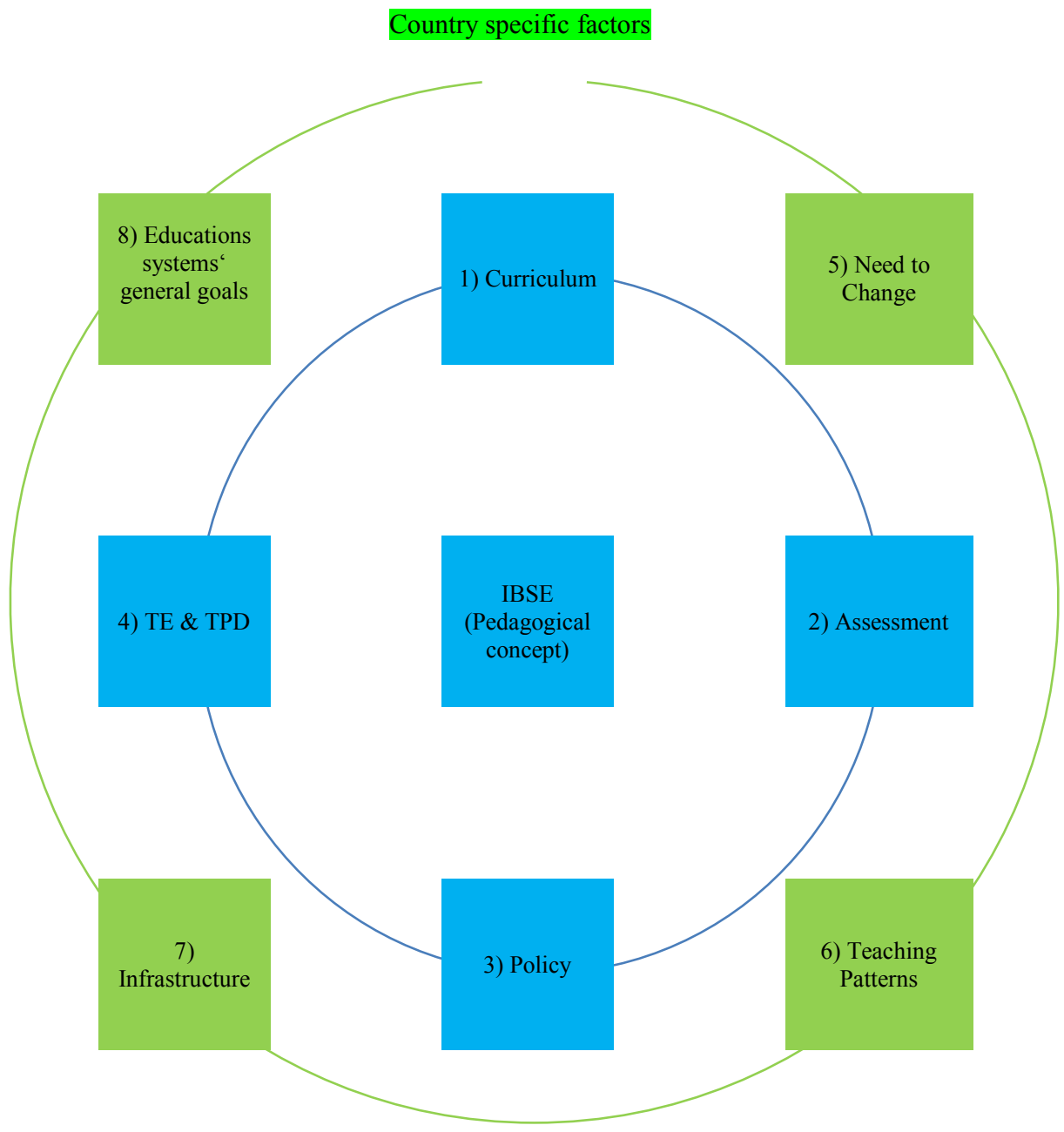




\section{Pedagogical Concept}

Workshop participants discussed the broader contextual character and the pedagogical concept, e.g. the goals, contents and forms of educational reality of IBSE. They pointed out that elements, such as the greater responsibility of students in engaging in science learning, influence the attitudes of teachers and students towards this approach and their acceptance of practicing it. On the one hand, participants claim that IBSE necessitates new teaching skills and positive attitudes from the teachers but also from the students engaging in this teaching and learning approach. On the other hand, recordings show that IBSE can have a positive influence on student motivation to engage in science. In Israel, for instance, the chemistry curriculum had seen little change since 1948 until around 2000 (Taitelbaum, Mamlok-Naaman, Carmeli and Hofstein, 2008). According to the stakeholders in the national workshop, this stagnation saw ever-falling number of students enrolled in high-school chemistry courses which eventually lead to a reform. The reform sought to make chemistry more relevant and was led by scientists, chemistry educators and teachers. According to the chemistry educators in the national workshop, the involvement of the teachers was crucial to the success of the new curriculum and in a few years the number of students taking a non-obligatory chemistry lab as part of their matriculation exam has risen from zero to $90 \%$.

Reservations about IBSE are expected in connection with its specific nature: workshop participants suggest that teachers might find it difficult to delegate their control and responsibility for learning to students. One participant in the workshop in Israel - a chemistry educator describes:

"The first time the teacher does inquiry (...) open ended - it is very frightening. What will be the results? Maybe it's not what I thought it was going to be and how can I explain to the students. So most of the time they begin with something which is very safe and when they get the confidence they try to do something new." (Israel, p1)

Moreover, the pedagogy of IBSE requires corresponding measures facilitating its 
implementation. As most teachers are unfamiliar with science inquiry they need support and opportunities to practice it, such as teacher training. The following statement illustrates the importance of teacher training that is adapted to the special needs of teachers:

"It is vital that we know how teachers perceive IBSE and especially what they perceive as constraints on, or disadvantages of, its adoption. This will enable us to address these constraints, either directly through deliverables such as training packages or indirectly by influencing policy." (Sweden, p1)

The analyses of the workshop recordings show that science educators need to obtain knowledge how teachers perceive IBSE. This knowledge can enable teacher educators to develop approaches and modules to foster teachers' didactic repertoire and positive attitudes towards IBSE. Besides supporting teachers' use of IBSE in their classrooms, the workshop participants argue, that students are also not used to this learning approach. This impression was articulated by participants in all workshops and is illustrated in the following quote from the workshop in the Czech Republic:

"The students are not used to such kind of work - it should start at primary school, so that the pupils will gain elementary skills for experimentation, otherwise it won't be productive. Some students are not capable enough for this way of work, they might loaf or bore." (Czech Republic, p3)

Participants in the Israeli workshop report that a gradual and long-term approach to get students used to working with science inquiry, as it was put into practice in chemistry, is effective:

"First they just make the observations, then they give the explanations and then they ask the questions. And sometimes they just get the experiment - just to do it. Then they design the experiment. Sometimes they just ask the questions and suggest hypotheses. If we do it from 10th to 12th grade all the time, then at the end they know what is inquiry." (Israel, p2)

Furthermore, workshop participants indicate that teachers perceive IBSE as very time consuming. Therefore, it is important, that the curriculum leaves enough space for its practice. 


\section{Curriculum}

Both the indicators "curriculum" and "assessment" refer to the necessity to adapt science curricula, and the way science competencies are tested, to the specific character of IBSE. The workshop participants agree that the science curriculum needs to define not only goals to be reached in science classes but also how science should be taught, e.g. using a particular teaching approach. As mentioned before, one difficulty in practicing IBSE is seen in its time-consuming character. With regard to the science curricula, participants complain that it does not leave enough time for practicing IBSE in science classes.

"The jammed curriculum doesn't allow for a reasonable proportion of such a way of teaching." (Czech Republic, p2)

"The way that the science curriculum is determined in a particular country will have an effect on the way in which science can be taught. Overcrowded or incoherent curricula may make it difficult to devote sufficient time to inquiry-based science teaching." (Sweden, p2)

Thus, participants request support from representatives in science policy, especially to implement IBSE in the science curricula in a way that allows for time to practice it.

\section{Assessment}

The workshop recordings furthermore show that the participants regard assessment methods as a key factor, influencing the way science is taught in schools. They agree that IBSE that is more likely to be practiced by teachers if assessments methods are able to capture its specific character. Therefore, representatives in educational administration can contribute to implementing IBSE by integrating assessment methods in standardized national and international tests that focus on skills students gain in practicing IBSE, e.g. knowledge about the nature of science or argumentation skills. A Swedish participant describes this connection between assessment methods and how 
science lessons are organized:

"As with the curriculum, assessment methods have a role in determining how science is taught. Even where inquiry is used extensively, excessive rigidity in assessment methods can constrain the usefulness of inquiry in promoting student motivation and interest." (Sweden, p1)

As expressed by a Turkish participant, teachers are under pressure because parents ask teachers to use assessment tools that are more aligned with the exams the student will take. Therefore, teachers prefer to use summative standardized assessment rather than any other assessment tools. The workshop participants strongly emphasize the importance of curricula and assessments methods adapted to IBSE. If the assessment tools are not capable of capturing skills students acquire by engaging with IBSE, it is likely that teachers will focus on different teaching and learning approaches. A representative of the Ministry of Education in Israel stresses this influence of the evaluation culture:

\footnotetext{
"You need to define the goals. And you need to assess. There is no other way to know if you reached the goals. In the process and at the end. So whether it's national or international exams doesn't matter. It can't be locally different - different with each teacher. Also you can't just rely on the teacher. In high school we have the matriculation exams and all the teachers (and I'm not very proud of it) teach for the exams and not the curriculum." (Israel, p2)
}

The indicators "curriculum" and "assessment" are closely related to the area of educational policy as the final decision-making authority rests here. Therefore, implementing IBSE depends to a large degree on convincing representatives of the educational policy to support this reform in science teaching.

\section{Policy}

The fourth indicator, "policy" describes how cooperation between schools, teacher professionalization systems on the one hand and policy on the other should be organized to facilitate the implementation of IBSE. The importance of co-operation between 
representatives of educational policy and teacher educators is described as follows:

"We need to know the views of policy makers since, for example, there may be forthcoming initiatives which provide opportunities for S-TEAM involvement." (Sweden, p2)

Stakeholders in policy are important for initiating reforms but also for implementing curricula and assessment methods that can facilitate implementing IBSE. Moreover, teachers need support in getting used to these changes and to actually apply reform teaching approaches. Thus, in Turkey, the science and mathematics curricula were changed in 2004 and revised in 2013. The most important features of the new curricula are that they aim to promote the use of inquiry based education and the use of alternative assessment strategies (MEB 2005). However, what this means in practice is not explicitly specified in the curricula (MEB 2013). Furthermore, teachers are not given enough resources or training to implement this approach in their classroom (MEB 2013). One of the participants from the National Ministry of Education said:

"Teacher training consists of two parts: pre-service and in-service teacher training. A centralized system is implemented in Turkey. Higher Education Council of Turkey set the pre-service program and Ministry of Education is responsible for in-service training. The new science curriculum focuses on inquiry based education. New graduate teachers may effectively implement these approaches in their classroom, but when we visit schools we are informed that other teachers who graduated in previous years use traditional approaches during their teaching. We need to train these teachers." (Turkey, p9)

Moreover, several participants claimed that there is not a strong coordination and collaboration between the National Ministry of Education and Higher Education Council of Turkey. Another issue discussed by the participants is the lack of long-term educational policies. One of the challenges that Turkey, Israel and the Czech Republic face is the unsustainable short-term cycle of policies in education. Over little more than a decade, the ministers of education in Turkey and the Czech Republic changed several times and each person in that role had different priorities, agendas and different approaches to science and mathematics education (Gür, Çelik, Coşkun and Görmez 
2014).

\section{Teacher professionalization systems}

Workshop participants attach substantial importance to integrating IBSE into effective courses in teacher education and TPD. Particularly, as most teachers and students are unfamiliar with IBSE, workshop participants call for a more comprehensive implementation of IBSE in teacher professionalization systems:

"...the teacher training must include IBSE in greater depth, both pre-graduate as well as a systematic TPD. Short term courses won't help so much.” (Czech Republic, p1)

With regard to the state of implementation of IBSE in teacher education, analyses of the workshop recordings reveal large differences between the countries and even within a country. Thus, while in Israel IBSE is integrated comprehensively in teacher education at universities; it is rarely covered in teacher education at colleges. One participant in the Israeli workshop, a researcher, notes that pre-service teacher training programs in universities manage to give teachers a "taste of doing inquiry", while teacher training programs in teacher training colleges give virtually no such training (Israel, p1).

Thus, workshop participants require a more comprehensive integration of IBSE into teacher education as well as TPD. In the Israeli workshop, for instance, a major concern expressed by several participants is that teachers themselves do not know how to conduct inquiry let alone guide their students in it. An Israeli researcher describes the problem in teacher training:

"I want to take it back to teachers. I think this is a key issue. The people from the ministry will forgive me, but I think a 56 hour professional development in inquiry is hardly enough for a teacher to facilitate inquiry based learning starting from 1st or 4th grade. Even in the high school where teachers formally are required to have a Master's degree - even if they have a Master's degree, they haven't necessarily conducted 
research. They can have a Master's without thesis. There is a minority of teachers with a thesis in the sciences." (Israel, researcher)

Besides supporting teachers with material and opportunities to practice IBSE, changing the attitudes towards IBSE is also regarded as important for getting teachers employing IBSE in their science classes. From the Israeli workshop a researcher summarizes his experience as follows: "most of the work was with teachers not with learning materials. It was to change teachers approach and give them the toolkit which will enable them to conduct inquiry projects". This statement is in line with findings - described above that teachers are the key actors in implementing innovations in the classrooms (Ostermeier, Prenzel and Duit 2010). Therefore, it is an important goal of teacher training and professionalization to develop positive attitudes towards reforms that affect their teaching practices.

\section{Discussion}

Science education experts discussed conditions important for implementing science inquiry more comprehensively in their education systems. They emphasized the need to support teachers and students in practicing science inquiry as well as the need of support from representatives in the area of policy to implement IBSE in professionalization systems and the curricula in the long-term. Qualitative analyses show that supporting measures should focus on the pedagogy of science inquiry. In particular, features like the open-endedness and the time consuming character are expected to cause difficulties in introducing IBSE in science classes. The participants agree that science inquiry can have a positive effect on students' motivation to engage with science matters, due to the student-centred qualities in IBSE that increase students' opportunity to participate and take ownership of their learning. However, they emphasize that students as well as teachers have less to little experience with using this 
approach. Thus, gaining experience and confidence in working with science during teacher education is particularly important. Results indicate that most teachers themselves have not experienced science inquiry as students. As teachers' didactic repertoires are influenced by their own experiences with science at school, it is not likely they will use IBSE in their classes, either. The maintenance of cultural teaching patterns revealed in the TIMSS video analysis demonstrates the difficulty of going beyond the influence of these experiences. If science inquiry is not practiced in school then teacher education should be organized with many opportunities for novice teachers to practice science inquiry. Nevertheless, there is evidence that programs in teacher education tend to offer few opportunities to learn science through inquiry, and thus provide little support for teachers in practicing. The qualitative analyses suggest that the way in which IBSE is integrated in teacher professionalization seems to differ greatly between the countries. Moreover, participants wish to improve teacher professionalization systems and see a need for more long-term TPD modules that will improve teachers' knowledge of and attitudes towards IBSE.

Furthermore, the qualitative analyses revealed that participants strongly emphasize that teachers will be more willing to practice IBSE if the science curriculum directly focuses it and if adequate assessment methods exist. The participants' statements confirm findings in research that indicate a lack of "readily accessible and meaningful assessments regarding educationally appropriate aspects” (Lederman et al. 2014, p. 66) of IBSE. Thus, there is a need to develop a new generation of measuring tools that are able to assess complex science learning as a result of practicing. 


\section{Results II: Which country specific frameworks influence the implementation of IBSE?}

The qualitative analyses of the workshop recordings lead to factors that are necessary to implement science inquiry in science education. Thus, science inquiry should be part of different areas in the education system, as in the curricula - with a special focus on appropriate assessment tools; furthermore it should be part teacher professionalization systems and its implementation depends on support by educational policy. The level of implementation of science inquiry in the areas the participants regard to be crucial, and thus the effects of the EU-project depend on the countries' specific structures and educational traditions. To explain how these specific characteristics influence the implementation of science inquiry, more detailed analyses are necessary; hence the Turkish, Israeli, Swedish and Czech education systems are examined in the following sections. These countries' education systems are analyzed with regard to the indicators found from the qualitative analyses: (1) curricula, (2) assessment, (3) policy and (4) teacher professionalization systems. In addition to a focus on the four indicators, which reflect the institutional environment (Meyer 2008), general features of each country's educational system and recent developments in schools' organizational environment (Powell and DiMaggio 1991) are discussed with regard to their influence on implementing science inquiry. We thereby answer the second research question that asks which country specific frameworks influence the implementation of IBSE. Further country specific factors arise from these analyses that influence the implementation of IBSE: (5) the need to change existing teaching approaches, (6) the predominant teaching pattern of a country, (7) an infrastructure that enables implementing IBSE and (8) educational system's general goals that correlate with the ideas of IBSE. We start with Turkey, as this case study represents the need to reform (5) most obviously. 


\section{Turkey}

In recent years, numerous social and economic changes in Turkey have affected the education system. Currently, trying to become a member of the European Union (EU) has been one of the main political objectives of Turkey. This European perspective contributed to reforms that aimed at meeting educational standards of European countries that are perceived as successful (Koc, Isildak and Bulut 2007). In 2012, compulsory basic education was increased from eight to twelve years (OECD 2012b). Due to these changes particular greater numbers of girls and pupils in rural areas now have access to education (Sezgin 2001, p.19). Thus, the number of pupils in Turkish classrooms is above the EU and OECD average, although it has been decreasing over the last ten years (OECD 2012a).

The higher enrollment rates are accompanied by an increase of students receiving higher education degrees. Thus, the OECD estimates that in 2015, if current enrolment rates remain constant, the number of 20-29 year-olds in higher education is likely to increase by more than 70\% in Turkey, compared to 2005 levels (OECD 2012a, p. 318). However, despite an expansion of the education system, more than $20 \%$ of young people in Turkey have the same low education levels as their parents (OECD 2012a, p. 109). More than $40 \%$ of all students in 2010 did not complete upper secondary education, and fewer than 20\% attend tertiary education (OECD 2012a, p. 103). In contrast, in 2010, 25 OECD countries had upper secondary attainment rates of $80 \%$ or more among 25-34 year-olds. The OECD estimates that while an average of 39\% of today's young adults in these countries will complete tertiary-type A (largely theorybased) education, less than 25\% of young people in Turkey will (OECD 2012a), which may indicate the importance of vocational education in Turkey (OECD 2012a, p. 109). 
The educational expansion has led to a need for enhanced teaching facilities like school buildings and teachers (Şengül, Çetin and Gür 2008). Thus, recent developments indicate that the major goals of the Turkish education system focus on the provision of a sufficient infrastructure to involve all children in the education system and to increase the number of pupils leaving school with higher education degrees (OECD 2012c). Therefore, the need for qualified teachers is an issue of particular concern. There is evidence that the need for more teachers was met by lowering the standards for becoming a teacher (Odabasi-Cimer and Cimer 2012, p. 21). Thus, there are a high number of inexperienced and perhaps even unqualified teachers (OECD 2012c). Moreover, the lack of motivation to become a teacher in the first place may have a negative impact on their professional ethos and attitudes towards their profession. Thus, summarizing experiences of Turkish participants in the S-TEAM national workshops, Jorde and others found that more than half of them did not communicate with colleagues and thought that society did not value their work; furthermore, $31 \%$ would change their profession if they could (2012).

Besides efforts of the Turkish education system to increase the number of young people in school, results of large scale student assessment studies indicate that the quality of science education also has to be improved (IEA 2012a). Turkey participated in TIMSS in 1999 and 2007 at the eighth grade, and ranked 33rd and 31st in science achievement in these years, respectively; however, looking at results from PISA, in 2012 Turkish students improved by 39 points compared to 2006 (OECD 2014). In PISA 2012, nearly half of the Turkish students (42\%) (OECD 2014) failed to reach the second-lowest level and therefore a basic level of basic science competency. Furthermore, only a small percentage of students $(0.3 \%)$ reached the highest competency level (compared to the OECD average of 1.1\%) (OECD 2014). 
The need for improving the quality of science teaching has led to changes in science education and the incorporation of innovative teaching approaches like IBSE. Following the piloting phase in schools in 2004-2005, a new curriculum was introduced in all Turkish schools in 2005-2006 academic year (İzci, Özden and Tekin 2008) and revised in 2013 (MEB 2013). The main focus of the curriculum is on constructivist teaching and learning approaches (MEB 2005). It emphasizes the active participation of students as well as knowledge of the nature of scientific thinking and scientific values (IEA 2012a). Inquiry-based science teaching is incorporated in science education curricula to a large extent. Additionally, an analysis of policy documents for science education features found that the following features of IBSE are strongly recommended: experiments and explanations, discussions and argumentation, project-work and use of specific ICT applications (Eurydice 2011). The strong focus on IBSE is also visible in assessment methods, recommended in official guidelines. Turkey is the only European country that suggests a variety of assessment methods for both primary and lower secondary levels of education. These range from traditional oral and written examinations, quizzes, project-based assessment, on-class performance assessment (including practical work), portfolios, self-assessment or peer-assessment (Eurydice 2011, p. 94). Thus, educational policy strongly supports implementing IBSE in Turkish science education (MEB 2013).

The actual use of the revised curricula in classroom science teaching depends on teachers' pedagogical knowledge. Studies investigating the cultural teaching patterns in Turkey come to contrasting results. While most studies criticize a rather traditional teaching approach (Odabasi-Cimer and Cimer 2012), large scale studies by TIMSS or Tina Seidel and colleagues show the predominance of science inquiry in most of the science lessons (Seidel et al. 2007). Thus, the implementation of IBSE is not only 
supported by its inclusion in science curricula but seems moreover to be facilitated by teaching methods, practiced by the majority of science teachers.

In conclusion, the implementation of IBSE in the Turkish education is facilitated by the support of educational stakeholders. The support of IBSE approaches by politicians responsible for education led to the implementation of IBSE into curricula and assessment methods, which are regarded as necessary conditions for its use in science classes by the participants of the national workshops. Furthermore, the cultural teaching patterns in Turkey seem to already contain many elements of science inquiry. Thus, this factor has a positive effect on implementing IBSE in science teaching. If teachers already have experience with IBSE, it will be easier for them to expand its use on a larger scale.

From the case of the Turkish education system the following additional categories (to the indicators found as a result of qualitative analyses of the workshops) can be generalized: The implementation of IBSE depends on an infrastructure that includes basic conditions, such as school buildings, laboratories, and effective teacher professionalization systems that provide teachers with pedagogical knowledge to use IBSE. In Turkey, finding a sufficient number of qualified science teachers is an urgent requirement. The low scores of Turkish students in standardized student tests demonstrate a further condition that facilitates implementing IBSE: the need to improve the education system. Therefore, drawing up on neo-institutional theories, there are two driving forces for recent educational reforms in Turkey: a European perspective and the wish to improve the students' successes in large scale comparative student assessment studies. 


\section{Israel}

Constituted as a democratic nation, Israel has looked up to European nations and the USA as its role models (as witnessed by Israel accession to the OECD in 2010). This affinity has also affected the realm of science education in the country. For example, Israel has participated for many years in international studies such as PISA and TIMSS, which have left a marked influence on educational policies and standards (Hofstein, Eilks and Bybee 2011). Its poor performance in national and international standardized tests have sparked a number of policy reforms in science education influenced by those in Europe and the USA (such as the high impact "Tomorrow '98" report from the Ministry of Education Culture and Sport in 1992). From a neo-institutional theoretical view the affinity to the West has been a significant driving force in science education policy and reform.

However, two dampening forces have slowed down such reforms. Israel has a very diverse population to which it caters by providing different educational streams (Jewish secular, Jewish religious, Jewish ultra-orthodox, Arab and Druze) (Hemmings 2010). The multiplicity of educational movements poses great difficulties when trying to implement reforms, especially with the ultra-orthodox stream which is almost completely autonomous. Another impediment to science education reforms is the high staff turnover rates in the ministries of education in the last three decades (Fortus, Mualem and Nahum 2009). This has made reaching a consensus on long-term viable educational reforms in science education and general education virtually impossible. This also means that the ministry of education lacks the ability to learn from past mistakes. So while many agree that education must be reformed, there is no agreement about which policies and actions to pursue. Thus, there are internal forces in the Israeli 
educational systems which resist the isomorphic effects of educational policy (Heinze and Knill 2008).

With regard to the factors that influence the implementation of science inquiry, Israeli workshop participants' views indicate that IBSE is not sufficiently integrated in all types of teacher education. These concerns are supported by a study that was conducted in the S-TEAM project, which found that there are huge differences concerning the quality of teacher education between universities and teacher training colleges (Jorde et al. 2012). There are no special programs devoted to IBSE in teacher education, though it is well implemented in biology and chemistry courses (Jorde et al. 2012). Although teacher education has improved since the 2010/11 academic year and must comply with the "Guidelines of Teacher Training" approved by the council of higher education, there is still no standard curriculum across all teacher education programs (Jorde et al. 2012).

As a result of several revisions, IBSE has been implemented in the Israeli science curricula for primary, lower secondary and upper secondary schools on a large scale (Sadeh and Zion 2012, p. 835). Thus, two different curricula for high schools were developed. The first focuses on the science orientated students, while the second "Science and Technology for all" - focuses on non-science orientated students (Mamlok-Naaman 2007, p. 199). In the curricula for non-science students the aim is to foster scientific literacy while remedying their shortcomings, especially poor attitudes towards science (Mamlok-Naaman 2007). Inquiry-based science teaching is included in both curricula, especially in the one for science-oriented students. Irit Sadeh and Michal Zion (2012) explain: "In Israel, high school biology students who take the final examination must study some theoretical subjects (60\%), perform lab assignments (20\%), and conduct a practical inquiry project (20\%). The Israeli Biology Syllabus for high school students, who major in biology, offers two different teaching approaches for 
the project which the teacher chooses: either guided or open inquiry" (Sadeh and Zion 2012, p. 835). Furthermore, standards were developed and introduced in 2004 that specify the curricula and support its implementation in science instruction (Klieger and Yakobovitch 2011, p. 287).

Although IBSE is part of the science curricula, there is evidence that its implementation is hindered by an insufficient infrastructure. Thus, besides improving science education the science curricula reforms aimed at increasing the number of education hours, which had decreased by $9.2 \%$ in elementary schools and by $20 \%$ in junior high schools due to budget cuts in education in the 1980s (Volansky 2007). As Caroline Kearney shows, despite official recommendations, less time is usually spent by schools on teaching the science and technology curriculum than is suggested. Therefore, the allocation of weekly teaching hours for science and technology were increased by the Ministry of Education with a minimum of four hours per week in the 7th grade and 5 hours per week in the 8th and 9th grade (Kearney 2012, p. 19). As seen in the case of Turkey, in Israel the implementation of the science curricula requires providing the necessary infrastructure, too. In addition to increasing teaching hours, schools were upgraded with science laboratories as the curricula for science subjects includes units that take place in the laboratory (Abd-El-Khalick et al. 2004, p. 398). Furthermore, several efforts were made to increase the number of qualified science teachers, who are lacking in primary schools in particular. The authors of the TIMSS 2011 Encyclopedia, who analyze the education policy and curriculum in mathematics and science, argue: "In spite of the recommendation and efforts to professionalize teaching, a shortage of suitable candidates for available positions, mostly in primary schools, prevents the realization of these recommendations. To date, about 50 percent of primary school teachers have a scientific background that meets the recommended criteria" (Mullis et 
al. 2012, p. 448). Other studies point to teachers' low salary and the large number of pupils in classes that hinder teachers in providing effective science instruction (Shavit and Blank 2012, p. 112). These conditions may have an adverse effect on the implementation of science inquiry as teachers need to be familiar and motivated to enact these curricula changes in science teaching.

While Turkish science lessons are characterized by many elements of science inquiry, studies investigating the predominant cultural teaching pattern in Israel indicate rather traditional teaching approaches in science instruction (Barnea, Dori and Hofstein 2010). In a survey conducted within the EU-project S-TEAM, respondents indicated that in the classroom, inquiry-based science teaching is used to some extent (Jorde et al. 2012). Accordingly, participants feel that there needs to be more courses on IBSE as many teachers have never tried IBSE themselves and find this approach difficult. Israeli science teachers therefore need comprehensive support as well as qualification programs. Furthermore, there is evidence that many Israeli teachers face discipline problems in their classes (IEA 2012, p. 441). Yossi Shavit and Carmel Blank, for instance, show in a study comparing eight countries with regard to classroom management that Israeli students are less disciplined on average and are more likely to be victimized than the average student in the other countries (Shavit and Blank 2012, p. 120). They explain that:

"Its dominant Jewish culture celebrates informality, contempt of authority, and defiance. Israeli classes are usually large, teachers are poorly paid, and most of them feel ill equipped to handle undisciplined and violent students. While Israeli legislators share teachers' concern about school discipline and violence, actual legislation and policy directives tend to safeguard and promote students' civil rights and to impose strict limitations on the sanctions that teachers and principals can employ in their attempts to enforce discipline in schools" (Shavit and Blank 2012, 129). 
The lack of teachers' authority in the classroom might act as a barrier to implementing inquiry-based science teaching. Science inquiry methods are studentcentered as this teaching approach reduces the teachers' control in having the knowledge and structuring the lessons. Depending on the degree of students' active role in conducting science inquiry (open vs. guided inquiry) students decide, for instance, on the questions they want to answer and how to answer them. Thus, if Israeli teachers already have to cope with disciplinary problems in science instruction, they might strive for more control in structuring the lesson and choose more traditional styles of teaching. Therefore, programs to qualify teachers to practice IBSE need to put special focus on the issue of discipline.

To conclude, these studies show that the implementation of IBSE is supported by its comprehensive inclusion in the curricula and standards in Israeli science education. Its implementation depends on having an appropriate infrastructure, with more support for teachers in practicing IBSE. Here, Israeli participants see special need for integrating more courses on IBSE into teacher education as well as TPD more comprehensively. Moreover, the missing long-term support by stakeholders in educational policy as well as mandatory curricula for all types of science education act as barriers in implementing science inquiry on a large scale.

\section{Sweden}

In general, teacher education and TPD are the responsibility of the head of individual universities and influenced by local authorities (Jorde et al. 2012, p. 24). Teacher education programs are available at 28 universities/colleges in Sweden. The degree of implementation of IBSE varies due to the decentralized structure of teacher education and TPD in Sweden (Jorde et al. 2012, p. 24). There are no mandatory programs or 
standardized TPD modules. Thus, empirical studies show that IBSE is rather rudimentarily integrated into teacher education and TPD (Establish 2011). In the TIMSS country report on science education for instance, Ina Mullis and colleagues investigated how often teachers participated in TPD programs and what the focus of these programs was. On average, $58 \%$ of all teachers in the report, but only $24 \%$ of the Swedish teachers participated in a module that focused on science pedagogy/instruction; similarly, $43 \%$ of all teachers, though only $13 \%$ of the Swedish teachers attended a program that offered opportunities to improve students' critical thinking or inquiry skills (Mullis et al. 2012, p. 304).

Nevertheless, IBSE has been more fully integrated in the science curricula since the revision of the science curriculum in 2011 (Sunderberg and Wahlström 2012). At the same time new curricula for the primary and secondary school systems were launched (Lgr 11 and Gy2011). Mullis and colleagues show that the Swedish curriculum and syllabi for science puts much emphasis on "knowing basic science facts and principles; providing explanations or justifications about what is being studied, designing and planning experiments or investigations, conducting experiments or investigations" and less emphasis on "applying science in real-life contexts" (Mullis et al. 2012, p. 62). However, the elements prescribed by the science curricula are mainly goals and objectives but not instructional methods or processes (IEA 2012a, p. 50). As a result of several school reforms in Sweden, schools have become more autonomous and are run by municipalities; furthermore these reforms have led to a growth of the so-called independent schools. Teachers have more freedom to organize their lessons (IEA 2012a). Therefore, it is uncertain how teacher apply IBSE in their teaching in science classes. Karina Adbo and Keith Taber, for instance, show how Swedish teachers' freedom to interpret the national syllabus and its goals leads to major differences 
science classes, even within the same school. The teaching style is, therefore, highly dependent on the individual teacher (Adbo and Taber 2009, p. 760). Furthermore, teachers are not recommended to use any particular methods of assessment by the official guidelines (Eurydice 2011).

In general, the predominant teaching patterns in Swedish science classes seem to incorporate few elements of IBSE (Mullis et al. 2012). Thus, according to a study by the EU-project Establish, the majority of teachers practice IBSE approximately a quarter of the time in their classroom (Establish 2011). Similarly, in their study on typical teaching pattern, usually employed in science classes in countries participating in PISA 2006, Seidel et al. (2007)found that science teaching in Sweden contains some elements of IBSE, like explaining ideas, drawing conclusions from experiments and students connecting findings to their experiences outside school (51\% of the science lessons). Lessons which contained a few elements of science inquiry were observed in $30 \%$ of the science lessons; lessons which contained many elements of IBSE appeared in only $18 \%$ percent of the time (Seidel et al. 2007).

Difficulties in implementing the new science curricula, therefore, seem to lie in the lack of focus on IBSE in teacher education and TPD. However, more attention on IBSE is necessary to encourage teachers to more fully incorporate this teaching approach. The lack of a comprehensive focus on IBSE in teacher education and TPD creates unfavorable framework conditions for changing the predominant teaching practice and implementing IBSE in the Swedish science education. Rather, educational policy focuses on initiatives to improve teachers' status and competence. Thus, besides efforts to improve the schools' equipment and technology (ALLEA Working Group 2012, p. 79) to provide better conditions for science education in Sweden, the most urgent problem is seen in the lack of qualified teachers (Ottander and Ekborg 2012, p. 1148). 
As a study by the Swedish National Agency for Education shows, the proportion of qualified teachers in municipal schools was $86 \%$, in the independent compulsory schools only 67\% (Swedish National Agency for Education 2012, p. 26). Therefore, one significant goal of the Swedish education policy in recent years has been the increase in teachers' education levels and professional standing rather than the promotion of IBSE (Mullis et al. 2012).

Thus, a new teacher education curriculum was launched in 2010, called "Top of the class - new teacher education programs", and the degree of Bachelor/Master of Education was replaced by four new professional degrees: a degree in pre-school education, a degree in primary school education, a degree in subject education and a degree in vocational education. Furthermore, teachers can work part-time and receive salaries for their participation in projects aimed to enhance their science competence. The government also arranged for investments in science and technology education and for science museum visits during 2009-2011 (Ministry of Education and Research 2009). In this context, two TPD- programs are particularly important in Sweden: The program "Lärarlyftet" (Development of Teachers) and "Science and Technology for All” (NTA). Since 2011, Lärarlyftet is provided for teachers, so they can reach new qualifications. The courses are mainly subject courses and/or subject didactic courses to enable teachers applying the new curriculum. Beginning with grade 4, science in the curriculum is differentiated in biology, chemistry and physics, while from pre-school to grade 3 there is an integrated science and technology curriculum. The second program, NTA started in 1997 as a project by the Royal Swedish Academy of Science and the Royal Swedish Academy of Engineering Science in cooperation with the municipalities throughout Sweden. In April 2007 the participation had increased to 70 municipalities and ten independent schools (a total of 66000 students and 4000 teachers) and has 
continuously grown since then. NTA provides teachers with 14 units developed in the US and another four units developed in Sweden. Each unit consists of a teacher and pupil book and laboratory material for an entire class. Teachers wishing to use NTA have to attend two general education meetings and two specific training sessions for every thematic area. The units are adapted versions of the Science and Technology for Children curriculum, developed by the National Science Resources Center, and Carolina Biological Supply Company. NTA is based on the Swedish national curriculum and syllabi, but does not satisfy all the goals specified. Teachers are free to further develop the NTA materials and can take part in additional development work as part of NTA (www.nta.se).

The need to change existing structures and methods in science education tends to be connected with students' achievements in comparative studies like TIMSS or PISA. However, recent publications in the area of educational research indicate that it is not so much the scores of Swedish students that have received much attention but consequences of neoliberal reforms to the educational system. Susanne Wiborg, for instance, describes how these reforms (voucher schemes, school choice, national testing and strengthening of private-state partnerships) introduced features of a quasi-market system into education (Wiborg 2013, p. 411). In another study, Dennis Beach and Marianne Dovermark (2011) investigate whether neo-liberal strategies in education strengthened the hegemony of the ruling class and thereby hampered the ideals of inclusiveness and equality in Scandinavian countries.

Summing up, the recent developments in Swedish science education appear to constitute adverse conditions for a more comprehensive implementation of IBSE. The focus in science education is primarily on strengthening teachers' qualifications and raising their status. Other problems include the high dropout rate of students in the 
vocational school tracks, youth unemployment and how recent trends of neo-

liberalization can be reconciled with the ideals of promoting equality in schools (Skans 2007). Additionally, the missing focus on IBSE in international projects, teacher education and TPD impede the implementation of IBSE. Even, if there were a national strategy to promote IBSE, the decentralized structure in education and the autonomy of Swedish teachers hinder the dissemination IBSE on a larger scale. Science inquiry has become part of discourses about improving science education mainly due to funding from the EC.

\section{Czech Republic}

The Czech educational system has undergone significant changes following the political and social upheavals of 1989. Therefore, the school system was decentralized in 2001 and 2003 (Eurydice 2011). In addition to the Ministry of Education, Youth and Sports regional education authorities and municipalities hold the responsibilities for schools (Mullis et al. 2012). In the process of decentralization, the lack of a coherent and longterm perspective to reform science education seems to have adversely affected the implementation of innovative teaching approaches like IBSE. As Jorde et al. (2012) show in a study that was conducted within the project S-TEAM, stakeholders in the Czech science education have experienced a constant change of staff in the area of educational policy and administration that has been accompanied by changes in accented issues, including teaching approaches. These experiences have contributed to an atmosphere of decreasing stakeholders' support for new reforms in teaching science as demonstrated in the following quotation:

"...one minute researchers are told that the Ministry has millions to distribute to different projects if they only write an application. The next minute the Minister is replaced and with that the priorities change. The research communities/the teacher 
educators are tired because of the lack of stability as they often find themselves in a situation where they spend a lot of time and effort writing proposals in vain" (Jorde et al. 2012, p. 50).

As the success of inquiry approaches depends to a great amount on support from educational policy and teachers (Istance, Benavides and Dumont 2010) these experiences have an unfavorable impact on initiatives to implement IBSE. Educational reforms, including an upscale of IBSE should be based on detailed reports of school functioning and mechanisms, how to improveme them (Levin 2008). The reform has to describe not only what has to be changed, but also why this new setup will work better than the previous one. And this is missing in Czech trials to implement IBSE to a larger extent. Besides, in recommendations of policy documents some parts of IBSE, such as: "recognizing issues that are possible to investigate scientifically", "evaluating explanations", "self-directed (individual) project work" have been recommended only for the level of secondary education. The learning goal "justifying explanations "is not found in policy suggestions for science education nor is the use of "use of specific IT applications" (Eurydice 2011, p. 72).

With regard to the implementation of IBSE in teacher education and TPD, studies show great variability in teacher education programs as the universities are quite autonomous and there are no national frameworks, beyond recommendations concerning the content of the programs (Jorde et al. 2012). Similarly, TPD courses offer a mixture of approaches in science and subject didactics, ranging from theoretical and practical parts to experience orientated courses. In these courses students learn the pedagogical and psychological background of IBSE and didactical approaches that facilitate introducing it into classroom teaching (Jorde et al. 2012). There are, however, very few elements of IBSE in teacher professionalization (ALLEA Working Group 2012). 
Empirical investigations of science instruction in Czech classrooms show that inquiry-based science teaching is rather seldom practiced (ALLEA Working Group 2012, p. 41). Analyzing videos of eighth-grade science lessons in the Czech Republic, Kathleen Roth and colleagues summarize the predominant teaching patterns as containing the following elements: "whole-class teacher-student talk about challenging, often theoretical content" (Roth et al. 2006b, p. 149). Basic features of instruction are review, assessment and development of canonical science knowledge. The video analysis showed that relatively little time was allocated for students to work independently on practical activities (Roth and Garnier 2006). Accordingly, assessment methods contain predominantly written and oral examinations (Eurydice 2011, p. 94).

Moreover, results of large scale student assessment studies show that Czech students performed above average in science tests in PISA 2000 (OECD 2007) and in TIMSS 1995, 1999 and 2007, although the average scale of the eight-grade decreased from 1995 to 2007 and in the fourth-grade from 1995 to 1999 in the TIMSS study (Martin 2008). In PISA 2009 students' scores were not statistically different from the OECD average (OECD 2007).

In summary, the picture emerges that the main features of the Czech science instruction constitute rather difficult conditions for implementing IBSE, which are related both to the proximal as well as distant factors influencing the possible change. The pronounced obstacles are the changing focus of educational policy as well as the rare inclusion of IBSE in teacher education and TPD. Additionally, good achievements of students in large scale assessment studies suggest there is no urgent need to change existing teaching practices. The main forces influencing the Czech educational system and emanating from the European codified educational policies are the necessity to 
improve evaluation and assessment capacities within the whole system (Santiago, Gilmore and Nusche 2012) and strengthen the teacher professional development system.

\section{Conclusions}

Studies with a neo-institutionalist background point to global pressures that lead to the emergence of similar models of education worldwide. There are calls to improve science education by supra-national reforms via means of disseminating best-practice models of education, like the S-TEAM project, via supporting transnational agreements and an increase of comparability of education systems' effectiveness. A result of the European co-operations of science experts in the case of the project S-TEAM is a consensus about conditions necessary to implement reforms. Thus, from the workshop participants' discussions it emerged that there are cross-border factors influencing the implementation of science inquiry. In general, the pedagogical concept of IBSE necessitates correlating supporting measures, like TPD modules that focus on features like students' greater control for learning and teachers' attitudes towards this teaching approach. With regard to indicators influencing the implementation of science inquiry as presented in figure 1, this study emphasizes (1) that the curricula need to be clearly focused on this teaching and learning approach. The case studies of the countries' educations system showed that IBSE is more likely to be implemented on a large scale if it is part of national science curricula, as is the case in Israel biology curricula; and if there are national curricula obligatory for teacher education and TPD. Thus, in Turkey the curricula's focus on IBSE has facilitated its implementation. In contrast, the implementation of IBSE in Swedish science classes depends to a large extent on the individual teachers who are free to choose which teaching methods to use in their classes. In addition, the qualitative analyses showed that assessment methods (2) have a 
substantial impact on the use of IBSE by teachers. Which types of assessment methods are practiced in a country is influenced by the structure of the curriculum and the predominant teaching style. While in Turkey the new focus on science inquiry in the science curriculum is accompanied by a mix of assessment methods recommended in official guidelines, in the Czech Republic a teacher focused science instruction is paired with traditional forms of assessment, like oral or written exams. Furthermore, (3) support from stakeholders in science education, especially in educational policy, is needed to implement IBSE in science curricula, teacher education and TPD. The instability of the Czech educational policy, as well as the lack of consistency in supporting particular approaches to improve science education, contributed to a progressive fragmentation of IBSE implementation and inability to establish consistent and long term initiatives in science education. Thus, currently in the Czech Republic there are programs, which provide financial support for schools to buy equipment for laboratories or for designing IBSE-orientated TPD modules. However, there are no corresponding TPD programs or networks between schools and universities; additionally many teachers simply confound IBSE with problem based teaching or constructivist approaches, showing little understanding of that approach. Moreover, the implementation of IBSE depends on effective training modules for teacher training (4). Analyses show large differences between the countries' teacher professionalization systems as well as between organisations within one country. In general, the workshop participants requested more long-term modules in teacher education and TPD that offer support for teachers in applying IBSE. The discussion of these four factors already points to the importance of each country's structural features as well as cultural attitudes and behaviours in implementing science inquiry.

In addition to these factors that emerged from the science experts' discussions, the 
analyses of the single countries' education systems revealed further conditions that influence the degree to which science inquiry will be implemented. Thus, our case studies on the countries' education systems show that new teaching approaches like IBSE are supported when stakeholders in science education recognize a need to change existing structures and science teaching methods (5). In all four countries of this study, the students' low or average scores in large comparative assessment studies were used to legitimate reforms in science education. The case study of Turkey made apparent the need to revise the science curricula leading to a focus on science inquiry. Moreover, a country's predominant teaching pattern (6) is a factor influencing its willingness to implement IBSE. Whether or not a country's cultural teaching pattern is similar to IBSE is a condition, influencing the degree to which teachers will have to expand their pedagogical teaching strategies. We assume that it will be easier to implement IBSE in science, when the teaching style predominantly used in the country's science lessons already contains many elements of IBSE than in countries where teachers mainly use traditional ways of teaching. In this study, the teaching patterns in Turkey and the Czech Republic exhibited the greatest differences. Science inquiry is suggested to be practiced in the majority of Turkish science lessons, while the Czech lessons tend to contain few features of science inquiry. More effort and professional support would, therefore, be necessary to convince and enable teachers in the Czech Republic to use IBSE. Likewise, reform initiatives depend on a correlating infrastructure in the education system (7), e.g. sufficient numbers of schools, laboratories or science lessons. The existence of qualified teachers plays a particularly important role in implementing IBSE in science education. Except for the Czech Republic (The master degree in science education is required for science teachers by school law and the proportion of unqualified teachers is negligible - below 5\% - in the Czech Republic) in the countries 
examined in this study, much effort was undertaken to increase the number and qualification of science teachers. In some countries, however, the primary focus of teacher professionalization programs is typically not on IBSE, as is particularly evident in the case of Sweden. Similarly, the support for IBSE is higher if it correlates with the general objectives that the education system of a country is pursuing (8). Reforms in education are then given higher priority. While not the highest priority, one goal of Israel's science education is to improve attitudes of non-science students towards science subjects. Therefore, science inquiry has become part of the curriculum for nonscience students, too.

In conclusion, we found global forces driving toward isomorphism in education systems - such as supranational reforms, benchmarking, disseminating effective teaching practices via EU projects and supporting transnational communication of science experts by supra-national organizations - as suggested by neo-institutional theories. In this study the perceived need to improve students' science literacy, resulting from large scale student assessment studies, contributed to initiating reforms to improve science education. Furthermore, the orientation toward the EU and the USA, as seen in Turkey and Israel, facilitates convergence tendencies in the countries' education systems. However, the influencing factors leading to convergence are impacted by many country-specific features. Thus, the S-TEAM projects' attempts to disseminate IBSE were hindered by a lack of corresponding educational infrastructures and the absence of a long-term focus from the policy stakeholders. Moreover, the countries' educational goals that often targeted other priorities than implementing science inquiry, as well as differing cultural teaching traditions reduced the EU projects' influence. Thus, pan-European policies will only be successful if they pursue a long-term goal and take into account these country specific influences. 


\section{References}

Abd-El-Khalick, F., Boujaoude, S., Duschl, R., Lederman, N. G., Mamlok-Naaman, R., Hofstein, A., Niaz, M., Treagust, D., \& Tuan, H.-1. (2004). Inquiry in science education: international perspectives. Science Education 88(3), 397-419. doi: 10.1002/sce.10118

Adbo, K., \& Taber, K. S. (2009). Learners' mental models of the particle nature of matter: a study of 16-year-old Swedish science students. International Journal of Science Education, 31(6), 757-786. doi:10.1080/09500690701799383

ALLEA Working Group Science Education. (2012). A renewal of science education in Europe: views and actions of national academies analysis of surveys conducted in 2010 and 2011. Retrieved August, 08, 2012 from http://www.allea.org/Content/ALLEA/WG\%20Science\%20Education/ALLEA\%20Report_ A\%20renewal\%20of\%20science\%20education\%20in\%20europe.pdf

Barnea, N., Dori, Y. J., \& Hofstein, A. (2010). Development and implementation of inquirybased and computerized-based laboratories: reforming high school chemistry in Israel. Chemistry Education Research and Practice, 11(3), 218-228. doi:10.1039/C005471M

Beach, D., \& Dovemark, M. (2011). Twelve years of upper-secondary education in Sweden: the beginnings of a neo-liberal policy hegemony? Educational Review, 63(3), 313-327. doi:10.1080/00131911.2011.560249

Bell, T., Urhahne, D., Schanze, S., \& Ploetzner, R. (2010). Collaborative inquiry learning: models, tools, and challenges. International Journal of Science Education, 32(3), 349-377. doi:10.1080/09500690802582241

Bruno, I. (2009). The "indefinite discipline" of competitiveness benchmarking as a neoliberal technology of government. Minerva, 47(3), 261-280. doi:10.1007/s11024-009-9128-0

Bybee, R. W. (2010). The teaching of science: 21 st century perspectives. Arlington, Va: National Science Teachers Association.

Campbell, T., Zhang, D., \& Neilson, D. (2011). Model based inquiry in the high school physics classroom: an exploratory study of implementation and outcomes. Journal of Science Education and Technology, 20(3), 258-269. doi:10.1007/s10956-010-9251-6

Casotti, G., Rieser-Danner, L., \& Knabb, M. T. (2008). Successful implementation of inquirybased physiology laboratories in undergraduate major and nonmajor courses. AJP: Advances in Physiology Education, 32(4), 286-296. doi:10.1152/advan.00100.2007

Corbin, J., \& Strauss, A. (1990). Grounded theory research: procedures, canons and evaluative criteria. Zeitschrift für Soziologie, 19(6), 418-427.

Dobbins, M., \& Knill, C. (2009). Higher education policies in central and eastern Europe: convergence toward a common model? Governance-an International Journal of Policy Administration and Institutions, 22(3), 397-430. doi: 10.1111/j.1468-0491.2009.01445.x

Drori, G. S., \& Meyer, J. W. (2006). Scientization: making a world safe for organizing. In M.-L. Djelic \& K. Sahlin-Andersson (Eds.), Transnational governance. Institutional dynamics of regulation (pp. 31-52). Cambridge, UK, New York: Cambridge University Press.

Duschl, R. (2008). Science education in three-part harmony: balancing conceptual, epistemic, and social learning goals. Review of Research in Education, 32(1), 268-291. doi:10.3102/0091732X07309371

Elmore, R. F. (1996). Getting to scale with good educational practice. Harvard Educational Review, 66(1), 1-26.

Elmore, R. F., \& Fuhrman, S. H. (1995). Opportunity-to-learn standards and the state role in education. Teachers College Record, 96(3), 432-457.

Establish. (2011). Report on how IBSE is implemented and assessed in participating countries. Retrieved August, 17, 2012, from http://www.establish-fp7.eu/project/publications 
European Commission. (2007a). Towards more knowledge-based policy and practice in education and training. Luxembourg.

European Commission. (2007b). FP7 in brief: how to get involved in the EU 7th framework programme for research. Luxembourg.

Eurydice. (2011). Science education in Europe: national policies, practices and research. Brussels: Agence exécutive "éducation, audiovisuel et culture.

Fortus, D., Mualem, R., \& Nahum, T. L. (2009). Science and technology in the junior high school - the contribution of yesterday to tomorrow: what can be learnt from the "tomorrow 98" programme. Rehovot, Israel: Weizmann Institute of Science.

Fullan, M. (2010). The role of the district in tri level reform. In E. B. \&. B. M. Penelope Peterson (Ed.), International encyclopedia of education (6th ed., pp. 295-302). Oxford: Elsevier.

Fullan, M. (2002, April). The three stories of education reform. Kappan Professional Journal. Retrieved October 08, 2014, from http://www.michaelfullan.ca/articles/\#2002.

Furtak, E. M., Seidel, T., Iverson, H., \& Briggs, D. C. (2012). Experimental and quasiexperimental studies of inquiry-based science teaching: a meta-analysis. Review of Educational Research, 82(3), 300-329. doi:10.3102/0034654312457206

Guskey, T. R. (2010). Professional development and teacher change. Teachers and Teaching, 8(3), 381-391. doi:10.1080/135406002100000512

Gür, B. S., Çelik, Z., \& Özoğlu, M. (2012). Policy options for Turkey: a critique of the interpretation and utilization of PISA results in Turkey. Journal of Education Policy, 27(1), 1-21. doi:10.1080/02680939.2011.595509

Gyllenpalm, J., Wickman, P., \& Holmgren, S. (2010). Teachers' language on scientific inquiry: methods of teaching or methods of inquiry? International Journal of Science Education, 32(9), 1151-1172. doi:10.1080/09500690902977457

Hemmings, P. (2010). "Israeli education policy: how to move ahead in reform". OECD economics department working papers, no. 781. Paris: OECD Publishing.

Heinz, J., Lipowski, K., Gröschner, A., \& Seidel, T. (2012). Indicators and instruments in the context of inquiry-based science education. Münster: Waxmann.

Heinze, T., \& Knill, C. (2008). Analysing the differential impact of the Bologna process: theoretical considerations on national conditions for international policy convergence. Higher Education, 56(4), 493-510. doi:10.1007/s10734-007-9107-z

Henderson, A. T., \& Mapp, K. L. (2002). A new wave of evidence: the impact of school, family, and community connections on student achievement. Austin, TX: Southwest Educational Development Laboratory.

Hiebert, J., Morris, A. K., Berk, D., \& Jansen, A. (2007). Preparing teachers to learn from teaching. Journal of Teacher Education, 58(1), 47-61. doi:10.1177/0022487106295726

Hiebert, J., \& Stigler, J. W. (2000). A proposal for improving classroom teaching: lessons from the TIMSS video study. The Elementary School Journal, 101(1), 3-20. doi:10.1086/499656

Hofstein, A., Eilks, I, \& Bybee, R. (2011). Societal issues and their importance for contemporary science education - a pedagogical justification and the state-of-the-art in Israel, Germany, and the USA. International Journal of Science and Mathematics Education 9(6), 1459-1483. doi:10.1007/s10763-010-9273-9

Inter Academics Panel. (2006). Report of the working group on international collaboration in the evaluation of inquiry-based science education (ibse) programs. Retrieved December 20, 2011, from http://www.interacademies.net/File.aspx ?id=7078

International Association for the Evaluation of Educational Achievement (IEA). (2012). TIMSS 2011 encyclopedia: education policy and curriculum in mathematics and science: (Volumes 1 and 2). Retrieved September 12, 2012, from http://timssandpirls.bc.edu/timss2011/downloads/TIMSS2011_Enc-v1.pdf 
Istance, D., Benavides, F., \& Dumont, H. (Eds.). (2010). Educational research and innovation. The nature of learning: using research to inspire practice. Paris, s.l: Centre for Educational Research and Innovation. Retrieved September 26, 2012, from http://site.ebrary.com/lib/alltitles/docDetail.action?docID=10421663

İzci, E., Özden, M., \& Tekin, A. (2008). Evaluation of new primary science and technology curriculum: sample of Adiyaman. Journal of Turkish Science Education, 5(2), 70-81.

Janmaat, J. G., Duru-Bellat, M., Méhaut, P., \& Green, A. (Eds.). (2013). Education, economy and society. The dynamics and social outcomes of education systems. Basingstoke: Palgrave Macmillan.

Jorde, D., Olson Moberg, A., Rönnebeck, S., \& Stadler, M. (2012). Workpackage 2: final report. Oslo, Norway.

Karseth, B., \& Solbrekke, T. D. (2010). Qualifications frameworks: the avenue towards the convergence of European higher education? European Journal of Education, 45(4), 563-576. doi:10.1111/j.1465-3435.2010.01449.x

Kearney, C. (2012). Efforts to increase students' interest in pursuing science, technology, engineering and mathematics studies and careers: national measures taken by 21 of European schoolnet's member countries - 2011 report. Brussels, Belgium: European Schoolnet (EUN Partnership AISBL).

Klieger, A., \& Yakobovitch, A. (2011). Perception of science standards' effectiveness and their implementation by science teachers. Journal of Science Education and Technology, 20(3), 286-299. doi:10.1007/s10956-010-9253-4

Koc, Y., Isildak, M., \& Bulut, S. (2007). Elementary school curriculum reform in Turkey. International Education Journal, 8(1), 30-39.

Lederman, J. S., Lederman, N. G., Bartos, S. A., Bartels, S. L., Meyer, A. A., \& Schwartz, R. S. (2014). Meaningful assessment of learners' understandings about scientific inquiry-the views about scientific inquiry (VASI) questionnaire. Journal of Research in Science Teaching, 5l(1), 65-83. doi:10.1002/tea.21125

Levin, B. (2008). How to change 5000 schools: a practical and positive approach for leading change at every level. Cambridge, MA: Harvard Education Press.

Linn, M. C., Davis, E. A., \& Bell, P. J. (2004). Inquiry and Technology. In M. C. Linn, E. A. Davis, \& P. J. Bell (Eds.), Internet Environments for Science Education (pp. 3-27). Mahwah, New Jersey: Lawrence Erlbaum Associates.

Mamlok-Naaman, R. (2007). "Science and technology for all" - an Israeli curriculum based on new standards in science education. In D. Waddington (Ed.), Standards in science education. Making it comparable (pp. 199-220). Münster: Waxmann.

Martin, M. O. (2012). TIMSS 2011 international results in science. Chestnut Hill, Mass: TIMSS \& PIRLS International Study Center.

Martin, M. O. (2008). TIMSS 2007: international science report: findings from IEA's trends in international mathematics and science study at the fourth and eighth grades. Boston, MA: IEA TIMSS \& PIRLS.

Meyer, J. W. (2008). Reflections on institutional theories of organizations. In R. Greenwood (Ed.), The SAGE handbook of organizational institutionalism (pp. 790-813). Los Angeles, London: SAGE.

MEB (Turkish Ministry of National Education) (2005). Science and technology curriculum (6-8 grades). Ankara: Milli Eğitim Bakanlığı Talim ve Terbiye Kurulu Başkanlığı. Retrieved July 27, 2015, from http://ttkb.meb.gov.tr/program2.aspx

MEB (Turkish Ministry of National Education) (2013). Science curriculum (3-8 grades). Ankara: Milli Eğitim Bakanlığı Talim ve Terbiye Kurulu Başkanlığı. Retrieved July 27, 2015, from http://ttkb.meb.gov.tr/www/guncellenen-ogretim-programlari/icerik/151 
Ministry of Education and Research. (2009). Uppdrag till Statens skolverk att genomföra utvecklingsinsatser inom matematik, naturvetenskap och teknik Regeringsbeslut 1:2 200902-19 U2009/914/GU2008/6186/G. Stockholm: Utbildningsdepartementet [Assignment to the National Agency to carry out development activities Mathematics, Science and Technology Government Decision]. Stockholm: Ministry of Education

Ministry of Education Culture and Sport. (1992). Tomorrow 98: report of the superior committee on science, mathematics and technology education in Israel. [Haim Harrari, chairman]. Jerusalem: Publications Department.

Mullis, I. V., Martin, M. O., Minnich, C. A., Stanco, G. M., \& Arora, A. (Eds.). (2012). TIMSS 2011 encyclopedia: education policy and curriculum in mathematics and science (Volumes 1 and 2). Lynch School of Education, Boston College: TIMSS \& PIRLS International Study Center.

National Research Council. (1996). National science education standards. Washington, DC: National Academy Press.

Naylor, S., Keogh, B., \& Downing, B. (2007). Argumentation and primary science. Research in Science Education, 37(1), 17-39. doi:10.1007/s11165-005-9002-5

Odabasi-Cimer, S., \& Cimer, A. (2012). Issues around incorporating reflection in teacher education in Turkey. Journal of Turkish Science Education, 9(1), 17-33.

Odden, A. (1991). Education policy implementation. Albany, N.Y: State University of New York Press.

OECD (2014). PISA 2012 results in focus: what 15-year-olds know and what they can do with what they know. Paris: OECD Publishing.

OECD (2012a). Education at a glance 2012: OECD indicators. Paris: OECD Publishing.

OECD (2012b). Science, technology and industry outlook 2012. Paris: OECD Publishing.

OECD (2012c). The experience of new teachers. Paris: OECD Publishing.

OECD (2011). PISA 2009 results: what students know and can do: student performance in reading, mathematics and science (Volume I). Paris: OECD Publishing.

OECD (2007). Programme for international student assessment (PISA) 2006: science competencies for tomorrow's world. Paris: OECD Publishing.

Orton, J. D., \& Weick, K. E. (1990). Loosely coupled systems: a reconceptualization. The Academy of Management Review, 15(2), 203-223. doi:10.2307/258154

Ostermeier, C., Prenzel, M., \& Duit, R. (2010). Improving science and mathematics instruction: the SINUS project as an example for reform as teacher professional development.

International Journal of Science Education, 32(3), 303-327. doi:

http://dx.doi.org/10.1080/09500690802535942

Ottander, C., \& Ekborg, M. (2012). Students' experience of working with socioscientific issues - a quantitative study in secondary school. Research in Science Education, 42(6), 1147-1163. doi:10.1007/s11165-011-9238-1

Powell, J. J. W., \& Solga, H. (2010). Analyzing the nexus of higher education and vocational training in Europe: a comparative-institutional framework. Studies in Higher Education, 35(6), 705-721. doi:10.1080/03075070903295829

Powell, W. W., \& DiMaggio, P. (1991). The new institutionalism in organizational analysis. Chicago: University of Chicago Press.

Roth, K., \& Garnier, H. (2006). What science teaching looks like: an international perspective. Science in the Spotlight, 64(4), 16-23.

Roth, K.J., Druker, S.L., Garnier, H.E., Lemmens, M., Chen, C., Kawanaka, T., Rasmussen, D., Trubacova, S., Okamoto, Y., Gonzales, P., Stigler, J., \& Gallimore, R. (2006). Highlights from the TIMSS 1999 video study of eighth-grade science teaching (NCES 2006-17). U.S. Department of Education, National Center for Education Statistics. Washington, DC: U.S. Government Printing Office. 
Sadeh, I., \& Zion, M. (2012). Which type of inquiry project do high school biology students prefer: open or guided? Research in Science Education, 42(5), 831-848. doi:10.1007/s11165011-9222-9

Santiago, P., Gilmore, A., \& Nusche, D. (2012). OECD reviews of evaluation and assessment in education. Paris: OECD.

Seidel, T., Prenzel, M., Wittwer, J., \& Schwindt, K. (2007). Unterricht in den Naturwissenschaften. In M. Prenzel (Ed.), PISA 2006. Die Ergebnisse der dritten internationalen Vergleichsstudie (pp. 147-179). Münster, München [u.a.]: Waxmann.

Şengül, S. H., Çetin, G., \& Gür, H. (2008). The primary school science teachers' problems in science teaching. Journal of Turkish Science Education, 5(3), 82-88.

Sezgin, A. R. (2001). Turkey's basic education programme: PEB exchange, programme on educational building, No. 2000/03. Paris: OECD Publishing. doi: 10.1787/862402283047

Shavit, Y., \& Blank, C. (2012). School discipline and achievement in Israel. In R. Arum \& M. Velez (Eds.), Studies in social inequality. Improving learning environments. School discipline and student achievement in comparative perspective (pp. 104-136). Stanford, Calif: Stanford Univ. Press.

Skans, N. O. (2007). School to work transition in Sweden: the japan institute for labor policy training report no. 5. Transition support policy for young people with low educational background. Tokyo: The Japan Institute for Labour Policy and Training

Swedish National Agency for Education. (2012). Facts and figures 2011: pre-school activities, school-age childcare, schools and adult education in Sweden. Retrieved May 7, 2015, from http://www.skolverket.se/publikationer?id=2768

S-TEAM (Science Teacher Education Advanced Methods). (2009). Science-teacher education advanced methods: the s-team project. Annex 1. Retrieved June 06, 2011, from https://www.ntnu.no/wiki/download/attachments/7242619/STAN84.pdf?version=1\&modific ationDate $=1243437674000$

Sundberg, D., \& Wahlström, N. (2012). Standards-based curricula in a denationalised conception of education: the case of Sweden. European Educational Research Journal, 11(3), 342-356. http://dx.doi.org/10.2304/eerj.2012.11.3.342

Taitelbaum, D., Mamlok-Naaman, R., Carmeli, M., \& Hofstein, A. (2008). Evidence for teachers' change while participating in a continuous professional development programme and implementing the inquiry approach in the chemistry laboratory. International Journal of Science Education, 30(5), 593-617. doi: 10.1080/09500690701854840

Volansky, A. (2007). School autonomy for school effectiveness and improvement: the case of Israel. In T. Townsend (Ed.), Springer international handbooks of education: vol. 17. International handbook of school effectiveness and improvement. Part one (pp. 351-362). Dordrecht, London: Springer.

Web of Science.

http://apps.webofknowledge.com/WOS_GeneralSearch_input.do?product=WOS\&search_m ode $=$ GeneralSearch $\&$ SID $=$ T1hYWaIfrSaHjR47OIU\&preferencesSaved=\&editions $=$ SSCI

Wiborg, S. (2013). Neo-liberalism and universal state education: the cases of Denmark, Norway and Sweden 1980-2011. Comparative Education, 49(4), 407-423. doi: $10.1080 / 03050068.2012 .700436$ 


\section{Author biographies}

Jana Heinz is a senior researcher at the TUM School of Education, Technische

Universität München in Germany. Her research interests include comparative sociological education, science inquiry as learning and teaching approach and indicators and measures in sociological education.

Margareta Enghag is a senior lecturer in Science Education, Department of Mathematics and Science Education at Stockholm University. Her areas of research are interaction and communication in the classroom, physics as a disciplinary discourse and students' access to the use of different representations and multimodality during physics education at secondary and tertiary education. A special interest is student ownership of learning during group work.

Iva Stuchlikova is a professor of Educational Psychology and works as the Head of Department of Pedagogy and Psychology at the Faculty of Education, University of South Bohemia, Ceske Budejovice. Her research interests are emotions and motivation, and professional development of teachers. She was awarded by the Early Career Award of The Stress and Anxiety Research Society in 2003 and served as Fulbright Senior Fellow at University of Minnesota in 2007. Her recent research projects are related to Inquiry Based Science Education and emotions in schools.

Gultekin Cakmakci is an associate professor of science education at Hacettepe University, Turkey. His research interests focus on developing scientific literacy among students and the general public and on the design, implementation and evaluation of science teaching.

Ran Peleg is a postdoctoral Fellow at University of Haifa. His current research interests include informal science education and embodied cognition in chemistry education. 
Ayelet Baram-Tsabari is an Assistant Professor at the Technion, and head of the

Biology Education and Science Communication research groups at the Department of Education in Science and Technology. She is a Landau Fellow for Leaders in Science and Technology Program, an Allon Fellow for Outstanding Young Researchers, and a member of the Learning in a Networked Society (LINKS) Israeli center of Research Excellence (I-CORE). 


\section{Executive Summary}

This empirical study investigates factors that influence the implementation of science inquiry in the education systems of Turkey, Israel, Sweden and the Czech Republic. Implementing science inquiry and thus improving European students' science competencies and attitudes towards science was the main objective the EU-funded project (2009-2012) called Science-Teacher Education Advanced Methods (S-TEAM). To study the factors that influence the implementation of reform teaching, like science inquiry, we employ a theoretical approach based on both the framework of neo-institutional theories and comparative studies. Thus, we combine research on the influence of supranational influences leading to global educational models and national explanatory variables that modify global pressures to convergence. We argue that the implementation of science inquiry is likely to be influenced by the characteristics of the countries' educational systems as well as by cultural traditions of science education exposing the key role of teachers' priorities and local political agendas. Data was collected by means of recordings of science experts' discussions that took place in national workshops in all participating countries of the project S-TEAM in 2009 and 2010. Important stakeholders of the countries' education system were invited to discuss the degree of implementation of science inquiry and ways to further disseminate this approach in science education. These discussions were recorded; the resulting database of this study includes the qualitative data from 66 participants from Turkey, Israel, Sweden and the Czech Republic. Results of the qualitative analysis reveal that the following general indicators provide insight into the extent of implementation of inquiry-based science education: (1) curriculum (2) assessment (3) policy and (4) teacher professionalization systems. In a second step comparative analyses of the four countries' education systems were conducted with regard to these indicators. Results show that in each of the countries these indicators influence the implementation of science inquiry to varying degrees. Moreover, as a result of the comparative analyses further country specific factors important for implementing science inquiry were found: (5) the need to improve existing teaching methods, (6) predominant teaching patterns, (7) infrastructure that enables changes in education and (8) education system's general goals that correlate with reforms. In conclusion, we found global forces driving toward isomorphism in education systems - such as supranational reforms, benchmarking, disseminating effective teaching practices via EU projects and supporting transnational communication of science experts by supra-national organizations - as suggested by neo-institutional theories. However, the influencing factors leading to convergence are impacted 
by many country-specific features. For instance, the S-TEAM projects' attempts to disseminate science inquiry were hindered by a lack of corresponding educational infrastructures and the absence of a long-term focus from the policy stakeholders. Thus, pan-European policies will only be successful if they pursue a long-term goal and take into account these country specific influences. 